\title{
Mechanisms of Aminoglycoside Ototoxicity and Targets of Hair Cell Protection
}

\author{
M. E. Huth, ${ }^{1,2}$ A. J. Ricci, ${ }^{1,3}$ and A. G. Cheng 1 \\ ${ }^{1}$ Department of Otolaryngology-Head and Neck Surgery, Stanford University School of Medicine, 801 Welch Road, Stanford, \\ CA 94305-5739, USA \\ ${ }^{2}$ Department of Otorhinolaryngology, Head and Neck Surgery, Inselspital, University of Bern, Freiburgstrasse, 3010 Bern, Switzerland \\ ${ }^{3}$ Department of Molecular and Cellular Physiology, Stanford University School of Medicine, 300 Pasteur Drive, Stanford, \\ CA 94305, USA
}

Correspondence should be addressed to A. G. Cheng, aglcheng@stanford.edu

Received 2 June 2011; Accepted 18 August 2011

Academic Editor: Jeffrey P. Pearson

Copyright (C) 2011 M. E. Huth et al. This is an open access article distributed under the Creative Commons Attribution License, which permits unrestricted use, distribution, and reproduction in any medium, provided the original work is properly cited.

\begin{abstract}
Aminoglycosides are commonly prescribed antibiotics with deleterious side effects to the inner ear. Due to their popular application as a result of their potent antimicrobial activities, many efforts have been undertaken to prevent aminoglycoside ototoxicity. Over the years, understanding of the antimicrobial as well as ototoxic mechanisms of aminoglycosides has increased. These mechanisms are reviewed in regard to established and potential future targets of hair cell protection.
\end{abstract}

\section{Introduction}

Aminoglycosides (AGs) are a well-known and successful class of antibiotics. The initial isolation of streptomycin from Streptomyces griseus provided the long-sought treatment for tuberculosis and an effective antibiotic against gram-negative bacteria $[1,2]$. In subsequent years, other AGs were isolated from Streptomyces spp., commonly integrating the ending "-mycin" in their nomenclature $[3,4]$. With the isolation of gentamicin from Micromonospora purpurea [5], the ending "-micin" was implemented to specify the bacterial origin of the individual AG. In contrast to these organic derivatives of soil-dwelling bacteria, synthetic AGs such as amikacin could be developed in vitro [6]. Currently, nine AGs (streptomycin, neomycin, tobramycin, kanamycin, paromomycin, spectinomycin, gentamicin, netilmicin, and amikacin) are approved by the Food and Drug Administration (FDA) [7].

In addition to their potent antimicrobial efficacy, all AGs can cause toxic side effects to the kidneys and inner ear. While damage inflicted by AG on the kidney is usually reversible $[8,9]$, damage to the inner ear is permanent [10]. This nephro- and ototoxicity was initially discovered in the first clinical trials of streptomycin $[11,12]$. Within the inner ear, streptomycin preferably damages the vestibular organ
[12]. Modification of streptomycin to dihydrostreptomycin, however, resulted in a shift of ototoxic damage from the vestibular organ to the cochlea [13]. Generally, each AG is capable of irreversibly damaging both the auditory and vestibular organs, but "typically affects one more than the other" [14]. Gentamicin and tobramycin are predominantly vestibulotoxic, whereas neomycin, kanamycin, and amikacin are mainly cochleotoxic [15]. Ototoxic side effects occur within days or weeks after systemic application and are often bilateral in presentation [16]. Vestibulotoxicity occurs in up to $15 \%$ of patients after AG administration [17], whereas cochleotoxicity in $2 \%$ to $25 \%$ of patients $[17,18]$. Different regimens of $A G$ administration and different definitions of ototoxic damage may have contributed to the variation of incidence [19].

Symptoms of cochleotoxicity include hearing loss and/or tinnitus, while those of vestibulotoxicity consist of disequilibrium and dizziness. Unfortunately, these symptoms may not be detected until after the acute phase of severe infection and diagnosis is thus delayed. AG cochleotoxicity typically affects first the high frequency and then extends towards the lower frequency and ranges over time in a dose-dependent manner $[20,21]$. Because the ultrahigh frequencies of hearing are not routinely tested $(>8 \mathrm{kHz})$, the true incidence 
of AG-induced hearing loss is often underestimated. Indeed, when ultra-high frequency testing was performed, hearing loss was reported in $47 \%$ patients with a history of AG treatment [22].

Despite the nephro- and ototoxic side effects, AGs are still the most commonly prescribed antibiotics $[23,24]$. In the industrialized world, use of AGs is usually limited to severe infections including those caused by multidrug resistant tuberculosis $[25,26]$. Neonates frequently receive AGs for suspected or proven gram-negative infection, as sepsis is associated with high mortality [27]. In the developing world, however, AG use has been popular because of their low cost and potent antibacterial activities, outrivaling more expensive antibiotics with less severe side effects. There, AGs are even prescribed as first-line therapy for less severe conditions such as bronchitis or otitis media [28]. Additional safety precautions such as blood level monitoring or hearing tests are also limited [19]. As a result, the incidence of AG ototoxicity in developing countries may increase in comparison to the industrialized world.

\section{Pharmacokinetics and Antimicrobial Mechanism of Aminoglycosides}

The AG class of compounds consists of an aminocyclitol moiety with two or more amino sugar rings [29]. A characteristic quaternary ammonium group makes AGs polycationic (positive charge) and highly polar [30, 31]. As a result, enteral absorption is poor and AGs are generally administered parenterally or topically [32]. After parenteral administration, AG plasma levels peak between 30 and 90 minutes $[7,33]$. Drug metabolism is minimal as approximately $99 \%$ of the administered AGs are eliminated unaltered by glomerular filtration in the proximal tubule $[34,35]$. The plasma half-life of AGs ranges from 1.5 to 3.5 hours $[7,36]$, but is prolonged in neonates, infants, and conditions with decreased kidney function [7, 37].

The most common indication to administer AGs is for empirical treatment of patients with severe infections such as septicemia, nosocomial respiratory tract infection, complicated urinary tract infections, and complicated intraabdominal infection [25], partly because AGs are shown effective against aerobic, gram-negative bacteria [38]. AGs demonstrate an increased selective antimicrobial activity in an alkaline environment [39]. It has been suggested that an alkaline $\mathrm{pH}$ compromises the bacterial membrane [40, 41], which might facilitate AG penetration into bacteria. Additionally, AGs have up to 6 amines with pKs varying more than two orders of magnitude, thus making the molecules much less charged at alkaline $\mathrm{pH}$ and so more able to interact with a lipid environment. Normally, the positively charged nature of the AG molecule precludes free passage through lipid barriers such as cell membranes, but promotes bacterial uptake and rapid binding to negatively charged lipopolysaccharides (LPS) in the outer membrane of gramnegative bacteria [42]. By competitive displacing bridging divalent cations such as $\mathrm{Mg}^{2+}$ or $\mathrm{Ca}^{2+}$, AGs can disrupt cross-links between adjacent LPS [43]. Such a disruption damages membrane integrity and leads to blebbing of the outer membrane, ultimately resulting in transient holes of the gram-negative cell wall $[44,45]$. This formation of holes in the cell wall facilitates further AG uptake and appears to significantly contribute to the bactericidal effect of AGs [46]. With this first step, AGs enter the periplasmic space of gramnegative bacteria in a passive and non-energy-dependent manner [47]. In a second step (also referred to as energydependent phase I), AGs are transported further through the inner bacterial membrane in an oxygen-requiring process [47]. Therefore, uptake is facilitated in aerobic bacteria [47]. Once in the cytosol, AGs interact with the 30S subunit of bacterial ribosomes $[48,49]$ in a third and energydependent step (energy-dependent phase II) [47, 50]. At the 30 S subunit, AGs bind to the decoding site located at the A site of the $16 \mathrm{~S}$ rRNA [51, 52]. Binding of AGs at this site perturbs the recognition and selection of tRNA during translation and increases misreading $[52,53]$. Furthermore, binding of AGs inhibits ribosomal translocation [54-56]. Perturbation of both ribosomal translation and translocation ultimately inhibits protein synthesis. Interestingly, the affinity for different rRNA binding sites varies amongst different classes of AGs [57-59]. This slightly different AGribosome interaction, therefore, appears to be beneficial against bacterial resistance [19].

\section{Ototoxicity and Mechanism of Hair Cell Damage}

3.1. Susceptibility and Genetic Predisposition for Aminoglycoside Ototoxicity. While AGs preferentially target the bacterial ribosome, the inner ear and kidney are known to receive collateral damage in many patients receiving treatment [11, 12]. However, a meta-analysis comparing once versus multiple-daily regimens of different AGs could not determine a statistical significant correlation between ototoxicity and treatment regimens [60]. One main susceptibility factor $(17 \%-33 \%$ of patients with reported ototoxic damage [61]) is the genetic predisposition to AG ototoxicity [62]. The fact that this increased susceptibility was inherited maternally suggested mitochondrial involvement [62]. This is compelling in light of the endosymbiotic theory as mitochondrial ribosomes demonstrate more similarities to prokaryotic ribosomes than cytosolic ribosomes [63, 64]. Therefore, the small subunit of the mitochondrial ribosome is one of the primary targeting sites for AGs [48, 49].

Several mutations in mitochondrial DNA are linked to increased susceptibility to AG ototoxicity $[61,65,66]$. Exposure to AG leads to impairment of RNA translation within mitochondria through interaction with binding sites on mitochondrial 12S rRNA [65]. This interaction was mapped to an adenine-to-guanine mutation at nucleotide 1555 in the $12 \mathrm{~S}$ rRNA gene [65]. Of additional note, bacterial resistance mutations are described at this locus $[67,68]$. This mutation increases structural similarity of mitochondrial rRNA to bacterial rRNA [65], which promotes binding of AG to mutated mitochondrial $12 \mathrm{~S}$ rRNA $[69,70]$. As a result, damage can result from decreased protein synthesis [69]. 
Although no direct evidence exists to link ototoxicity to an inhibition of mitochondrial protein synthesis, inhibition of mitochondrial protein synthesis potentiates AG toxicity [71]. Also, electron microscopy reveals mitochondrial disruption following AG treatment [72].

This susceptibility mutation has been reported in $17 \%$ $33 \%$ of patient with reported AG ototoxicity [61]; in the general population of the European Union, it is estimated to be $1: 500[73,74]$. Other mutations leading to increased AG susceptibility have also been described, including C1494T [66]. The C1494T mutations have varying degrees of penetrance [75], are less common than the A1555G mutation [76], and are sporadic with multiple origins [77]. In sum, the prevalence of the most common mutations across varying ethnic backgrounds is $0.9 \%-1.8 \%[76,78]$, of which $5 \%-6 \%$ are sporadic $[63,79,80]$.

Although this genetic susceptibility is present in all organs, the mitochondrial mutations target the cochlea but not the vestibular organs or the kidneys [81]. This is intriguing as this selective cochleotoxicity also occurs with preferably vestibulotoxic AGs such as streptomycin [81]. One proposed explanation for this phenomenon is that AGs cause misreading in mitochondrial protein synthesis rather than direct inhibition of protein synthesis [82] such that tissues rich in mitochondria would be predominately affected [81]. Exposure to AGs would decrease mitochondrial ATP synthesis resulting in compromised ion pump activity [81, 82]. Reduced ion pump activity in strial intermediate cells could ultimately lead to a progressive decrease of the endocochlear potential [81]. This scenario conceivably explains the slow progression of hearing loss after exposure to AGs observed in patients with increased genetic susceptibility [81]. The strial impairment, furthermore, would explain the little effect on vestibular function in these patients [81]. Interestingly, the stria vascularis demonstrates extensive degeneration in syndromal mitochondrial diseases [83]. This further supports the hypothesis of the stria vascularis as the cochlear cells targeted by the mitochondrial mutations in patients with increased genetic susceptibility to AG ototoxicity. An alternative simple explanation is that susceptibility to the mitochondrial disease is a function of metabolic demand so that hair cells operating at higher frequencies will be more susceptible to a reduced mitochondrial function than lower frequency cells, that is, cochlea versus vestibular, basal versus apical, and type I versus type II. Similarly the highly metabolically active strial cells would also have increased sensitivity.

In genetically susceptible individuals, it is postulated that a single injection of AG can cause ototoxic damage [84], implying that genetic factors can reduce the threshold concentration at which AGs cause damage [61]. At higher concentrations or more frequent doses of AG, the incidence of ototoxic damage exceeds the prevalence of genetic predispositions [76, 81, 85]. Although in vitro, a clear relationship between damage and AG concentration is observed, the extent of ototoxic damage in vivo does not seem to correlate with AG concentration in targeted tissues [86]. This discrepancy requires further evaluation.
3.2. Route of Aminoglycosides into Hair Cells. After systemic administration, AGs are detected in the cochlea within minutes. Fluorescently labeled gentamicin was detected in the stria vascularis 10 minutes after injection in mouse [87]. In the stria vascularis, the fluorescently tagged gentamicin increased over time mainly in marginal cells, but also in intermediate and basal cells as well as fibrocytes, plateauing after 3 hours [87]. These observations suggest that gentamicin enters the inner ear fluids from the strial capillaries through the strial marginal cells [87]. In the organ of Corti, fluorescence from labeled gentamicin starts increasing 1 hour after systemic injection. Hair cells demonstrate fluorescent gentamicin intracellularly after 3 hours [87]. Earlier studies demonstrated similar pharmacokinetics in rat and guinea pig $[88,89]$. In rat cochlear tissues, gentamicin concentrations were measured by a radioimmunoassay and peaked 3 hours after systemic application [89]. In guinea pig, gentamicin appeared in the stria vascularis 30 minutes after systemic injection. In outer hair cells (OHCs), gentamicin was detected after 30 minutes and peaked 6 hours after systemic injection [88]. Although these studies had different specific time points for measurements, they are roughly in agreement as to the time course of uptake into cochlear tissues [87-89]. Based on the cochlear structures, where AGs are located, entry into various cochlear structures suggests a complex uptake mechanism (Figure 1).

Both endocytosis and transport through ion channels are proposed to mediate AGs uptake into sensory hair cells. While some publications describe endocytosis as the mechanism of entry into hair cells $[90,91]$ others advocate for the mechanoelectrical transducer (MET) channel located at the top of hair cell stereocilia [92-94]. The endocytic mechanism of AG entry arose because researchers observed the appearance of vesicles in the subcuticular region of hair cells after systemic injection in guinea pigs [95]. Hashino and Shero observed kanamycin in intracellular vesicles 27 hours after systemic injection in chicken [90]. These findings were interpreted as evidence for endocytosis as mechanism of AG uptake as the vesicle membranes contained cationic ferritin, a membrane bound marker [90]. However, no differences in intravesicular AG, compared to a control group, were observed until 12 hours after injection [90].

Myosin7a was hypothesized to play a role in endocytosismediated AG uptake due to its concentrated expression at the apical part of hair cells in a region with high amounts of vesicles known as the pericuticular necklace $[91,96]$. The lack of AG uptake in Myosin $7 \mathrm{a}^{6 \mathrm{j}}$ mutant mice was considered evidence supporting AG toxicity mediated by endocytosis [91]. Further investigation found that Myosin7a-deficient hair cells exhibit closed MET channels at rest, confounding initial interpretations [97].

Furthermore, the rate of endocytosis correlates with temperature and, therefore, is decreased in hypothermic conditions [98]. AG uptake demonstrates little temperaturedependent kinetics, indicating a minor relevance of endocytosis in the process [99]. Instead, there is strong evidence that AGs enter hair cells through the MET channel located at the top of the stereocilia. AGs act as open channel blockers of the MET-channel [100, 101]. Initially, AGs 


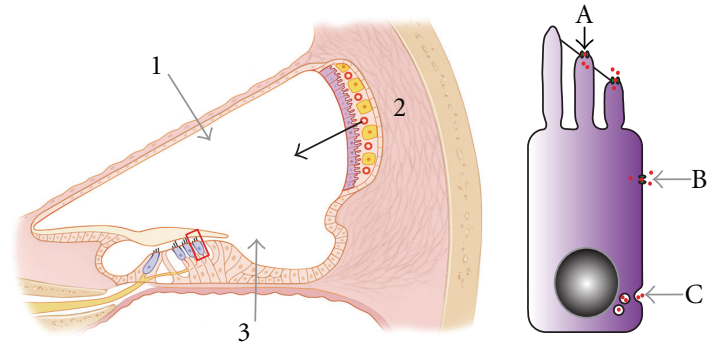

Figure 1: Proposed mechanisms of aminoglycoside transport in the inner ear. Possible entry sites for aminoglycosides into the scala media include via (1) the Reissner's membrane, (2) stria vascularis, and (3) basilar membrane. Published work supports the notion of entry via the Reissner's membrane and the stria vascularis through and between the marginal cells. At the hair cell level, aminoglycosides can potentially enter via mechanotransducer channels located on stereocilia of hair cells (A), endocytosis on the apical or basolateral membranes (A, B, or C), TRP channels (A, B or C), or ATP receptors (A).

were not considered to be permeable because diameter estimates of the MET-channel pore were low $(0.6 \mathrm{~nm})$ [102]. However, work by Gale and coworkers suggested that larger molecules could pass through the MET channel [103]. This was quantified by Farris et al. with a new pore size estimate of $1.25 \mathrm{~nm}$ [104], which is large enough to pass AGs. Marcotti et al. demonstrated directly that AGs could pass through the channel [92]. Interestingly, this block was decreased significantly for AG approaching the channel from the internal as opposed to the external face [92]. As this difference between internal and external blocking of AG makes the MET channel function like a one-way valve, intracellular accumulation of AGs is promoted and might explain the increased susceptibility of hair cells compared to other cell types [94]. The significance of the MET channel as a major route of AG entry is furthermore supported by the exacerbation of ototoxic damage with noise exposure [105]. Acoustic stimuli increase the open probability of the MET channel and thereby, increase AG uptake [106]. Additionally, the distribution of ototoxic damage with increasing hair cell susceptibility from apex to base corresponds to the transduction currents in the cochlea, which are larger in basal than in apical OHCs and, in general, more decreased in inner hair cells (IHC) [107-109]. Moreover, fluorescently labeled gentamicin has been observed first in the tips of hair cell stereocilia before the fluorescent signal increases in the hair cell body [87].

Several other ion channels might also contribute to AG uptake into hair cells. Channels of the transient receptor potential (TRP) class such as TRPC3, TRPV4, TRPA1, and TRPML3 are expressed in the cochlea [110-112] and are permissive to AGs in kidney cells $[113,114]$. It is unclear at this point under what conditions the TRP channels might be open and whether these channels are expressed in the plasma membrane or in other cytosolic compartments. The glycoprotein megalin is another potential mediator for AG uptake. Megalin is predominantly expressed in the proximal tubules of the kidney. Megalin is capable of binding AGs and is also expressed in the inner ear [115]. Therefore, it was considered a candidate protein for the uptake of AG into hair cells. However, megalin is a drug receptor engaging in endocytosis and is not expressed in the organ of Corti and sensory hair cells [115-117]. Notwithstanding, megalin has been detected in marginal cells of the stria vascularis, suggesting a role in the transport of AGs into the inner ear fluids $[116,117]$.

3.3. Apoptotic Pathways of Ototoxic Hair Cell Death. Inside the hair cell, AGs cause damage, either directly or indirectly, by first inducing disarray of stereocilia and ultimately ending with apoptotic cell death [118-121]. The presence of AGs within hair cells leads to increased formation of reactive oxygen species (ROS) or free radicals [122-125]. A common mechanism for the formation of ROS is the Fenton reaction:

$$
\mathrm{Fe}^{2+}+\mathrm{H}_{2} \mathrm{O}_{2} \longrightarrow \mathrm{Fe}^{3+}+\mathrm{HO}^{\bullet}+\mathrm{HO}^{-} .
$$

Here, the presence of iron salts is required [126]. When gentamicin combines with iron salts, the gentamicin-iron complex enhances iron-catalyzed oxidations and, thereby, directly promotes the formation of ROS [122]. This requires electrons for which unsaturated fatty acids can act as electron donors. In return, those fatty acids, predominantly arachidonic acid, are oxidized to lipid peroxides $[125,127]$. As arachidonic acid is an essential fatty acid present in cellular membranes, ROS can affect membrane fluidity and permeability $[128,129]$. Via lipid peroxidation, ROS can also affect proteins and nucleic acids thereby disrupting the activity of enzymes, ion channels, and receptors [128-131]. ROS naturally occur in the cell as a regular byproduct of cellular metabolism [130-132]. Normally, the cell protects itself from lethal ROS accumulation with intrinsic antioxidants such as glutathione $[132,133]$. This intrinsic protective system is capable of neutralizing ROS to some extent [134]. When formation of ROS, however, overwhelms the capacity of these intrinsic protective and repair systems, the cell then undergoes apoptotic cell death $[135,136]$.

The mechanism of involvement of mitochondrial mutations in ototoxic hair cell death is not completely understood. Exposure to AG leads to impairment of RNA translation and inhibition of protein synthesis within mitochondria $[65,69$, 137]. It is further suggested that inhibition of mitochondrial protein synthesis leads to a decrease in ATP [137]. With the decrease of energy production, the mitochondrial integrity is compromised and predispose to a leakage of cytochrome $\mathrm{c}$ and subsequent activation of the apoptotic cascades. Furthermore, it is hypothesized that the mitochondrial RNA mutations when exposed to AG cause an increased formation of ROS, which then promote apoptotic cell death [137].

Independent extrinsic and intrinsic apoptotic pathways exist $[138,139]$. The extrinsic pathway is mediated by death receptors including the tumor necrosis factor (TNF) family. When stimulated, death receptors activate cysteine-dependent, aspartate-specific proteases also known as caspases. The prototype of death receptors is the FAS 
(CD95/APO-1) receptor, which activates caspase- 8 on stimulation. Caspase- 8 in turn initiates a cascade involving the activation of caspase-3, caspase-6, and caspase-7, which ultimately execute cellular degeneration [140]. The intrinsic pathway, in contrast, is the major apoptotic pathway initiated by aminoglycoside ototoxicity (Figure 2) [120]. The intrinsic pathway is predominantly triggered by nonreceptor stimuli such as cytokine deprivation, DNA damage, and cytotoxic stress [141]. Characteristic for the intrinsic apoptotic pathway is the permeabilization of the outer mitochondrial membrane resulting in leakage of proapoptotic factors from the mitochondrial intermembrane space into the cytoplasm. Mitochondrial membrane integrity and components of the intrinsic pathway are regulated by proteins of the B-Cell Lymphoma-2 (Bcl-2) family [141].

$\mathrm{Bcl}-2$ is the prototype of this equally named protein family. Studies in other systems report these molecules as key apoptosis mediators, acting upstream of caspase activation [142-144]. The Bcl-2 proteins function as a checkpoint for cell death and survival signals in the mitochondria (Figure 2). The Bcl-2 protein family can be anti- or proapoptotic $[136,145,146]$; anti-apoptotic Bcl-2 proteins include Bcl-2 and Bcl- $\mathrm{X}_{\mathrm{L}}[143,147]$, whereas pro-apoptotic $\mathrm{Bcl}-2$ proteins which promote cell death include Bax, Bak, $\mathrm{Bcl}-\mathrm{X}_{\mathrm{s}}, \mathrm{Bid}, \mathrm{Bad}$, and Bim $[143,147]$. Bcl-2 proteins form hetero- and homodimers within the cell. When a cell is challenged, the balance between anti- and pro-apoptotic Bcl2 proteins regulate whether or not apoptotic cell death is initiated [148]. Anti-apoptotic Bcl-2 proteins are able to bind to pro-apoptotic Bcl-2 proteins, thus neutralizing the proapoptotic signal [149]. When the balance moves in favor of apoptosis, the pro-apoptotic cytoplasmic Bcl-2 member Bax translocates to the mitochondria, causing pores in the mitochondrial membrane $[143,144]$. This leads to loss of mitochondrial transmembrane potential, generation of ROS, and leakage of cytochrome $c$ into the cytoplasm [143, 144, 150-154], thus activating the upstream caspase pathway as mentioned above. Supporting a role of this pathway in the inner ear, hair cell loss, and caspase-9 activation were prevented in utricles from $\mathrm{Bcl}-2$ overexpressing mice when treated with neomycin [155]. This suggests a role for Bcl-2 in the upstream caspase cascade in aminoglycoside-induced hair cell death.

Another group of mediators of apoptotic hair cell death is the stress-activated protein kinases, including the mitogen-activated protein (MAP) kinases (Figure 2) [120]. A particular group of MAP kinases are c-jun N-terminal kinases (JNK). These JNKs are located in the cytoplasm and regulated by c-Jun-interacting protein-1 (JIP-1) [156, 157]. In response to cellular insults, JIP-1 facilitates the phosphorylation and thus activation of JNK [158-161]. Activated JNK in turn phosphorylates and thereby activates the transcription factors c-Jun, c-Fos, ELK-1, and activated transcription factor 2 (ATF-2) in the nucleus and Bcl-2 in mitochondria [120]. After AG treatment, increases in JNK, c-Jun, c-FOS, and Bcl-2 have been reported in hair cells $[120,152,161,162]$. Activation of the JNK signaling pathway appears to precede the release of mitochondrial cytochrome c, which then activates caspases $[152,163]$.

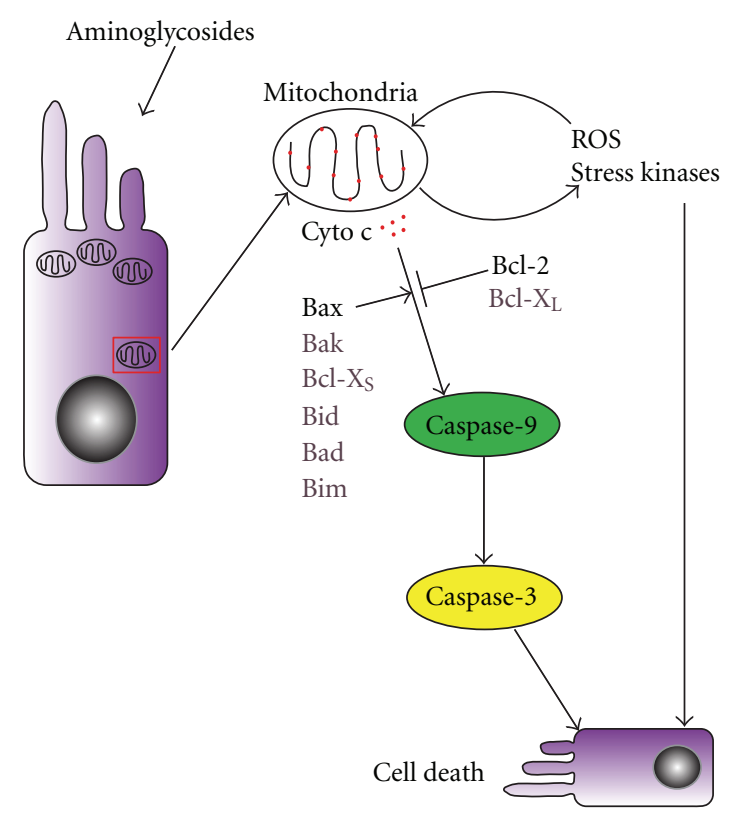

FIGURE 2: A simplified schematic of the cell death cascade in hair cells damaged by aminoglycosides. Reactive oxygen species (ROS), stress kinases, and the caspase family of proteases are activated and mediate hair cell degeneration caused by aminoglycoside exposure, whereas overexpression of $\mathrm{Bcl}-2$ protects against caspase activation and hair cell loss. Aminoglycosides damage the mitochondria and can result in generation of ROS and activation of stress kinases. Both ROS and stress kinases can cause cell death directly as well as amplify insults targeting the mitochondria. The balance between pro-apoptotic and anti-apoptotic Bcl-2 family members determines the integrity of the mitochondria. Cytochrome c leaking out of damaged mitochondria leads to caspase- 9 activation, which in turn activates caspase- 3 to execute cell death.

Caspases execute cell death in apoptosis [141]. The caspase family consists of 14 members in mammals, with only a subset involved in apoptosis $[142,164]$. Caspases can thus be segregated into upstream and downstream enzymes, which are normally inactive [136, 164]. Caspases exist in the cytoplasm normally inactivated by inhibitor of apoptosis proteins (IAP) [136, 141]. Activation of upstream caspases occurs by apoptosis-inducing signals such as p53, which has been shown to activate caspases after administration of cisplatin. Downstream caspases are activated by upstream caspases through cleavage of an inactivating prodomain to produce the mature enzyme [136].

Caspase- 8 is an upstream member that is tightly linked to membrane-associated death domain-containing receptors. When ligands such as Fas ligand or tumor necrosis factor alpha bind to this receptor, caspase- 8 is recruited intracellularly, leading to clustering and autoactivation of other caspase- 8 molecules [165]. This subsequently causes activation of downstream caspases such as caspases-3, -6, and -7. Although caspase- 8 is detected in HC after AG administration $[166,167]$, it does not play a key role in $\mathrm{HC}$ death, as inhibition of this pathway does not prevent $\mathrm{HC}$ death or prevent caspase-3 activation [166, 168, 169]. 
Caspase- 9 is an upstream caspase activated by apoptotic signals from the mitochondria. This pathway is initiated by cytochrome $c$ release from mitochondria, which then binds to apoptosis protease activating factor, dATP, in the cytoplasm and procaspase-9 $[164,170]$. This binding causes cleavage and activation of caspase-9, which subsequently cleaves and activates downstream caspases, ultimately resulting in apoptotic cell death (Figure 2). Activated caspase-9 is detected in cochlear and utricular hair cells after AG treatment in vitro $[151,166,167]$.

Caspase- 3 is a primary downstream caspase that executes the apoptotic program by cleavage of proteins necessary for cell survival, including Bcl-2, inhibitors of deoxyribonucleases, and cytoskeletal proteins (Figure 2) [171-174]. This enzyme activation has been detected in HC due to ROS after AG dosing [150, 151, 166, 167, 175].

Further mechanisms of apoptotic hair cell death following AG administration involve activation of $\mathrm{NF}-\kappa \beta$ as well as calcium-dependent proteases such as calpains. Inhibition of NF- $\kappa \beta$ in rat cochlear explants after exposure to gentamicin altered the ratio of activated over inactivated pro-apoptotic factors such as c-Jun and p38 as well as of anti-apoptotic factors such as akt [176]. Exposure of mice cochlear cultures to neomycin resulted in apoptotic DNA fragmentation, which could be prevented by a calpain inhibitor [177].

Overall, apoptotic death of hair cells due to AG exposure is complex and our understanding of it has increased in recent years. A simplified model of the apoptotic cascade in aminoglycoside damaged hair cells is presented in Figure 2, but it is important to point out that many components of the overall cascade and the interactions among these components are still poorly understood. This complexity is in part reflected by crosstalks among pathways. Death receptor stimulation, for example, is also capable of activating the intrinsic pathway despite primary involvement in the extrinsic pathway [141].

\section{Efforts in Hair Cell Protection}

With increasing understanding of ototoxic cell death, a myriad of therapeutic efforts have been proposed to target various steps of the complex cascades to hair cell death. Those strategies include inhibition of apoptosis, neutralization of ROS, and administration of neurotrophic factors. A detailed overview of relevant studies including applied drugs, dosage, and outcome is presented in a table at the end of each subchapter.

4.1. Inhibition of Apoptotic Enzymes. Permeable caspase inhibitors such as z-Val-Ala-Asp $(\mathrm{O}-\mathrm{Me})-\mathrm{CH}_{2}$ F-fluoromethyl ketone $(\mathrm{zVAD})$ were applied against different AGs in a variety of species. zVAD inhibits by irreversibly binding to the active site of a broad spectrum of caspases [167]. Caspase inhibitors conferred significant protection against hair cell damage from AG, preserving hair cell morphology as well as function in vitro and in vivo [167, 178-182] (Table 1).

Agents targeting upstream stress kinases in the apoptotic cascades also prevented AG-induced hair cell death. DJNKI-1 is a cell permeable peptide that binds to all three isoforms of JNK, thereby blocking JNK-mediated activation of the apoptotic transcription factor c-Jun [156]. Inhibition of the MAP-JNK pathway by application of D-JNKI-1 prior to treatment with neomycin resulted in significant protection from hair cell loss in vitro and hearing loss in vivo [161]. Other JNK inhibitors that successfully prevented AG ototoxicity are CEP-1347, CEP 11004, and 17 $\beta$-Estradiol [152, 183-186] (Table 1).

Targeting the Bcl-2 family as the upstream key mediator of apoptosis also prevented AG-induced hair cell loss. Overexpression of the anti-apoptotic Bcl-2 in transgenic mice significantly decreased hair cell loss and preserved hearing function following AG exposure in vitro and in vivo $[155,187]$. Inoculation of mouse cochlea with an adenovirus vector expressing the anti-apoptotic $\mathrm{Bcl}-\mathrm{X}_{\mathrm{L}}$ before treatment with kanamycin also protected from hair cell loss and preserved hearing function [188] (Table 1).

Another class of stress-activated proteins are the family of heat shock proteins (HSPs), which are upregulated in stressed cells in multiple organ systems. HSPs can not only prevent protein aggregation by promoting proper folding of nascent or denaturated polypeptides [189], but also inhibit apoptosis. Induction of HSP expression in cultured mouse utricle led to upregulation of HSP-70, HSP-90, and HSP-27 [190]. Overexpression of HSP-70 in transgenic mice significantly protected from hair cell loss from neomycin treatment in vitro, but also significantly protected from hearing loss and hair cell death in mice injected with kanamycin over the course of 14 days $[191,192]$.

Application of anti-apoptotic agents raises several concerns. The protective results of anti-apoptotic drugs are mainly based on acute studies. Therefore, the sustainability of therapeutic potential and safety remain to be evaluated in chronic exposure scenarios. There is evidence that the protective effects of caspase inhibitors to the inner ear are short term [167]. Considering that AGs are not metabolized $[7,34,73]$ and remain in the hair cells for months $[88,194]$, potential sustainable regimens would conceivably require long-term treatment. Unfortunately, long-term treatment with anti-apoptotic drugs bears a potential carcinogenic risk, as apoptosis has a crucial primary function in preventing uncontrolled cell proliferation [195]. This carcinogenic risk, therefore, prohibits potential application in human otologic patients. Whether this risk is decreased over a long period by local application to the inner ear remains to be studied. The therapeutic application of anti-apoptotic agents to rescue hair cells after AG exposure has not been reported, but is of further translational interest.

4.2. Neutralization of Reactive Oxygen Species. Aminoglycosides form complexes with iron, thereby, catalyzing the formation of ROS [122]. Competitive blocking of the Fenton reaction involved by iron chelators, thus, is a reasonable approach to avoid oxidative damage from the beginning. Therefore, much efforts aiming at prevention of AG-induced hair cell death have focused on iron. Administration of the iron chelators deferoxamine and 2,3-dihydroxybenzoate before AG exposure significantly attenuated hearing threshold shifts and protected from hair cell loss in vivo [196-198]. 
TABle 1: Overview of studies performed to protect from aminoglycoside ototoxicity by inhibition of apoptosis. C: Chicken, G: Gerbil, GP: Guinea Pig, M: Mouse, R: Rat, ZF: Zebrafish; X: in vitro, Y: in vivo; i.m.: intramuscular, i.p.: intraperitoneal, i.t.: intratympanic, s.c.: subcutaneous; d: day, h: hour; O: no effect, P/PP/PPP: partial, not significant/partial and statistically significant/complete and statistically significant protection.

\begin{tabular}{|c|c|c|c|c|}
\hline Therapy (dose) & Aminoglycoside (dose) & Species & Outcome & Reference \\
\hline $\mathrm{zVAD}(100 \mu \mathrm{M}, 26 \mathrm{~h})$ & Gentamicin $(0.1,0.5,2 \mathrm{mM} ; 24 \mathrm{~h})$ & C, X & PPP & {$[167]$} \\
\hline $\mathrm{zVAD}(100 \mu \mathrm{M}, 26 \mathrm{~h})$ & & & PPP & \\
\hline $\operatorname{BAF}(100 \mu \mathrm{M}, 26 \mathrm{~h})$ & Gentamicin (1 mM, $6 \& 24 \mathrm{~h})$ & $\mathrm{GP}+$ & PPP & {$[178]$} \\
\hline Deferoxamine (1 mM, 26h) & & $G, X$ & PPP & \\
\hline $\mathrm{zVAD}(300 \mu \mathrm{M}, 12 \mathrm{~h})$ & Neomycin $(10 \mu \mathrm{M}, 3 \mathrm{~h})$ & $\mathrm{ZF}$ & $\mathrm{PP}$ & {$[179]$} \\
\hline zVAD (local $50,100 \mu \mathrm{M}$ or $1.5 \mathrm{mg} / \mathrm{kg}$ i.m.) & Streptomycin (1.2 g/kg; $5 \mathrm{~d}, \mathrm{i} . \mathrm{m})$. & C, Y & $\begin{array}{l}\text { local PP } \\
\text { i.m. P }\end{array}$ & {$[180]$} \\
\hline $\begin{array}{l}\text { zVAD }(250 \mu \mathrm{M} \text {, local @ } 0.5 \mu \mathrm{L} / \mathrm{h}, 14 \mathrm{~d}) \\
\mathrm{zLEHD}(150 \mu \mathrm{M} \text {, local @ } 0.5 \mu \mathrm{L} / \mathrm{h}, 14 \mathrm{~d})\end{array}$ & $\begin{array}{l}\text { Gentamicin }(12 \mathrm{mg} / \mathrm{mL} \text {, local } \\
\text { @ } 0.5 \mu \mathrm{L} / \mathrm{h}, 14 \mathrm{~d})\end{array}$ & GP, Y & $\begin{array}{l}\mathrm{PP} \\
\mathrm{PP}\end{array}$ & {$[182]$} \\
\hline zDEVD $(10$ or $200 \mu \mathrm{M}, 48 \mathrm{~h})$ & & & $\mathrm{PP}(200 \mu \mathrm{M})$ & \\
\hline zIETD (10 or $200 \mu \mathrm{M}, 48 \mathrm{~h})$ & Gentamicin $(35 \mu \mathrm{M}, 48 \mathrm{~h})$ & $\mathrm{R}, \mathrm{X}$ & $\mathrm{O}$ & {$[193]$} \\
\hline zLEHD (10 or $200 \mu \mathrm{M}, 48 \mathrm{~h})$ & & & $\mathrm{O}$ & \\
\hline $\mathrm{zVAD}(100 \mu \mathrm{M}, 26 \mathrm{~h})$ & & $\mathrm{M}, \mathrm{X}$ & PPP & \\
\hline zIETD $(100 \mu \mathrm{M}, 26 \mathrm{~h})$ & Neomycin (1 mM, 24 h) & & $\mathrm{O}$ & {$[166]$} \\
\hline zLEHD (100 $\mu \mathrm{M}, 26 \mathrm{~h})$ & & & $\mathrm{PP}$ & \\
\hline d-JNKI-1 (M $2 \mu \mathrm{M}$; GP $10 \mu \mathrm{M}, 1 \mu \mathrm{L} / \mathrm{h}$ local, 7 d) & $\begin{array}{l}\text { Neomycin (M } 1 \text { mM, } 24-48 \text { h; GP } \\
300 \text { mg/kg i.p. } 5 \text { d) }\end{array}$ & $\begin{array}{l}\text { M, X } \\
\text { GP, Y }\end{array}$ & $\begin{array}{l}\text { PPP } \\
\text { PPP }\end{array}$ & {$[161]$} \\
\hline CEP-11004 (0.5 $\mu \mathrm{M}, 84 \mathrm{~h})$ & Gentamicin $(50 \mu \mathrm{M}, 72 \mathrm{~h})$ & $\mathrm{R}, \mathrm{X}$ & PP & {$[184]$} \\
\hline CEP-11004 (0.2, 0.4, 1.6, $4.8 \mu \mathrm{M} ; 7 \mathrm{~h})$ & Neomycin $(1 \mathrm{mM}, 3 \mathrm{~h})$ & $\mathrm{C}, \mathrm{X}$ & $\mathrm{PP}(1.6 \mu \mathrm{M})$ & {$[152]$} \\
\hline CEP-11004 (1.0 $\mu \mathrm{M} ; 24 \mathrm{~h})$ & Neomycin (1 mM, 24h) & $\mathrm{M}, \mathrm{X}$ & $\mathrm{PP}$ & {$[183]$} \\
\hline Estradiol $(1,10,100,1000 \mathrm{nM} ; 60 \mathrm{~h})$ & Gentamicin $(100 \mu \mathrm{M}, 48 \mathrm{~h})$ & $\mathrm{R}, \mathrm{X}$ & $\mathrm{P}$ & {$[185]$} \\
\hline CEP-1347 (1 mg/kg s.c., 1 x/d, 14 d) & Gentamicin $(120 \mathrm{mg} / \mathrm{kg}$ s.c., $1 \mathrm{x} / \mathrm{d}, 14 \mathrm{~d})$ & GP, Y & $\mathrm{PP}$ & {$[186]$} \\
\hline Bcl-2, transgenic & Neomycin (1 mM, 24h) & $\mathrm{M}, \mathrm{X}$ & $\mathrm{PP}$ & {$[155]$} \\
\hline Bcl-2, transgenic & Gentamicin ( $40 \mu$ g i.t., single dose) & M, Y & PP & {$[187]$} \\
\hline $\mathrm{Bcl}-\mathrm{X}(\mathrm{L})$, transgenic & Kanamycin $(800$ mg/kg, 2 x/d, s.c., 15 d) & $\mathrm{M}, \mathrm{Y}$ & PP & {$[188]$} \\
\hline HSP 70, transgenic & Neomycin (1-4 mM, 24 h) & $\mathrm{M}, \mathrm{X}$ & $\mathrm{PP}$ & {$[191]$} \\
\hline HSP-70, transgenic & Kanamycin $(700$ mg/kg, 2 x/d, s.c., 14 d) & $\mathrm{M}, \mathrm{Y}$ & PP & [192] \\
\hline HSP-70, transgenic & Kanamycin $(700$ mg/kg, 2 x/d, s.c., 14 d $)$ & $\mathrm{M}, \mathrm{Y}$ & $\mathrm{PP}$ & [192] \\
\hline
\end{tabular}

Acetylsalicylate (ASA) is another iron chelator with additional direct antioxidant properties. ASA prevents cleavage of PKC zeta, a key regulator of NF $\kappa \beta$ activated by exposure to amikacin [199]. Systemic administration of ASA effectively protects guinea pigs from gentamicin-induced hearing loss [200]. As ASA is a long-approved and routinely prescribed drug, application in human patients is the logical next step. In randomized, double-blind placebo-controlled studies, ASA significantly protected human patients from ototoxic damage without compromising the antimicrobial efficacy of gentamicin [201-203]. However, ASA itself is ototoxic and potentially causes tinnitus, vertigo, and hearing loss [204]. Although these symptoms are known to be reversible [204], AGs remain in hair cells for months $[88,194]$ and ototoxic damage can occur after many years [81]. Thus chronic treatment with ASA appears necessary and ototoxic effects of both, AGs and ASA, need to be evaluated over a long period. In this context, recent studies discovered a decrease of activity in auditory neurons in long-term treatment [205]. Of further concern is that AGs are frequently prescribed in children and neonates. ASA, however, is strictly contraindicated in children as it is associated with Reye's syndrome, which is a serious and often fatal disease predominantly affecting the brain and liver [206-208].

$\mathrm{N}$-Acetylcysteine (NAC) is another drug commonly used in patients. Beside its mucolytic effect, NAC is also a known antioxidant. In short-term cultures of guinea pig cochlea, AG alone caused less than $30 \%$ of basal OHC survival but $90 \%$ of the apical OHC survived. This observation correlated with lower levels of the intrinsic antioxidant glutathione in basal OHC. However, survival of basal OHC was significantly improved by cotreatment with NAC as well as glutathione and salicylate [209]. In hemodialysis patients who received gentamicin treatment for bacteremia, application of NAC resulted in significantly less high frequency hearing threshold shifts compared to a control group receiving gentamicin alone. Treatment with NAC was continued for one week after cessation of the gentamicin therapy and the protective effects persisted after another six weeks [210]. Compared to ASA, NAC does not demonstrate intrinsic ototoxic side effects. 
A myriad of other agents with known antioxidant capacity has been tested for protection and treatment of AG ototoxicity. These agents are primarily antioxidants such as D-Methionine (D-Met) [211-213] and $\alpha$-lipoic acid ( $\alpha$-LA) [214], vitamins such as $\alpha$-tocopherol (vitamin E) [215-217] and vitamin C [218] as well as the herbal extracts Gingko biloba [219] and Danshen [220]. The hormone melatonin, normally excreted by the pineal gland, also has antioxidant capacity and successfully protected from AG ototoxicity $[175,221-223]$. An alternative protective strategy against AG ototoxicity is the upregulation of intrinsic antioxidant mechanisms such as the superoxide dismutase (SOD) [209, 224, 225] (Table 2).

Overall, antioxidants attenuate ototoxic damage from AGs. However, the majority of antioxidants did not demonstrate complete protection from AG ototoxicity [211-213, 215-217, 227, 229] and effects of long-term treatment remain to be studied.

4.3. Alternative Otoprotective Strategies. There exists a number of alternative approaches to protect against AG ototoxicity. One intriguing approach is moderate exposure to ototoxic stimuli with the intent to increase intrinsic antioxidant mechanisms within the ear. Exposure to low doses of amikacin or gentamicin for 30 days and consecutive high-dose treatment for another 10 to 12 days resulted in significantly less morphologic and functional hair cell damage $[230,231]$ (Table 3). However, this bears the undesirable risk of increased bacterial resistance and, thereby, undermines the primary antimicrobial purpose of the AG application. Exposure to moderate noise also protects from gentamicin ototoxicity in gerbils [232] (Table 3). As this does not allow for immediate application of AG in therapeutic doses, applicability in human patients appears difficult.

Other studies successfully target NMDA receptors to protect auditory nerves $[233,234]$. However, the NMDA receptor antagonists dizocilpine and ifenprodil exist as maleate and tartrate salts, which carry intrinsic metal chelating properties [235]. Their vehicle, dimethyl sulfoxide (DMSO), can also act as a radical scavenger [236]. Therefore, the results of Basile and coworkers [233,234] were challenged by Sha and Schacht [237]. Nonetheless, NMDA antagonists do interact with receptors of afferent auditory nerve fibers [238]. Thus, targeting the auditory nerve appears reasonable as AGs interact with certain nerve synapses. AGs can aggravate myasthenia gravis and cause postoperative respiratory suppression suggesting a direct neuromuscular blockade [239-242] (Table 3). Presynaptically, AGs interfere with the calcium internalization essential for acetylcholine release [243]. At the postsynaptic level, streptomycin directly blocks the acetylcholine receptor primarily, whereas neomycin affects the open probability of the ion channel of the acetylcholine receptor [244]. Also, in rat and mouse cochlear cultures, fluorescently tagged gentamicin accumulates in the afferent auditory nerve fibers in addition to the hair cells [245].

This direct interaction with the auditory nerve also might explain therapeutic effects by neurotrophic growth factors. Ciliary neurotrophic factor (CDNF), glial-cell-line-derived neurotrophic factor (GDNF), brain-derived neurotrophic factor (BDNF), and neurotrophin 3 (NT-3) demonstrated partial protective effects against AG ototoxicity [213, 246250] (Table 3). The contribution of neurotrophic growth factors in preventing AG ototoxicity suggests an involvement of the auditory nerve. However, there is evidence that the effects of neurotrophic growth factors are short term. Local application of BDNF ( $62.5 \mu \mathrm{g} / \mathrm{mL}, 0.25 \mu \mathrm{L} / \mathrm{h}$ over $28 \mathrm{~d})$ to guinea pigs exposed to kanamycin $(400 \mathrm{mg} / \mathrm{kg}$, single dose, s.c.) and furosemide $(100 \mathrm{mg} / \mathrm{kg}$, single dose, i.v.) demonstrated initial protection from ototoxicity. Cessation of the therapy, however, resulted in an accelerated neuronal degeneration and after another $14 \mathrm{~d}$, the survival of BDNFtreated auditory neurons did not differ from the deafened, untreated control animals [251].

Ethacrynic acid (EA) is a diuretic which increases AG ototoxicity when administered simultaneously [252]. Delayed co-treatment with application of EA 12-18 hr after gentamicin injections in guinea pigs resulted in significantly protected hair cell function and morphology [253]. The authors suggest that EA disrupts the blood-labyrinth barrier, thus creating a gradient promoting efflux of AG from the inner ear fluids back into the bloodstream. However, the protective effects are time dependent and could not be found when EA was injected $20 \mathrm{hr}$ after the AG [253]. Moreover, simultaneous $A G$ and EA in patients resulted in ototoxic damage after a single treatment [254], thereby excluding EA as a treatment option.

Overall, prevention of apoptotic hair cell death following $\mathrm{AG}$ exposure has been targeted effectively on various levels. Direct inhibition of apoptotic cascades resulted in functional and morphological preservation of hair cells. Neutralization of free radicals by antioxidants prevented activation of apoptotic enzymes. Furthermore, application of NMDA-receptor antagonists, neurotrophic growth factors, and sound conditioning have prevented ototoxic hair cell damage from AG. However, these protective results are mainly based on acute studies and the sustainability of therapeutic potential and safety remains to be evaluated in chronic exposure scenarios or in clinical trials.

\section{Potential Targets for Hair Cell Protection}

In light of recent insight and increasing understanding of the mechanisms involved in AG ototoxicity, newer and more effective targets may be revealed in the near future. Those target sites involve the mitochondrial rRNA as well as AG entry into the inner ear fluids and hair cells. Considering the one-way valve function of the MET channel as a site of AG entry into hair cells $[92,94]$, the prolonged persistence of AG in hair cells poses another obstacle to overcome [194]. Therefore, avoiding entry of AG into hair cells is potentially promising. On the level of the MET channel, at least two possibilities of preventing AG entry exist. The first one involves a reversible block of the MET channel. The process of hearing requires depolarization of the inner hair cell through the MET channel [101, 260, 261]. Blocking of the MET channel would then prevent hair cell depolarization and, therefore pause hearing function. Thus, the MET 
TABle 2: Overview of studies performed to protect from aminoglycoside ototoxicity by antioxidants. C: Chicken, CH: Chinchilla, G: Gerbil, GP: Guinea Pig, H: Human, M: Mouse, R: Rat, ZF: Zebrafish; X: in vitro, Y: in vivo; i.m.: intramuscular, i.v.: intravenous, i.p.: intraperitoneal, i.t.: intratympanic, s.c.: subcutaneous, RWM: round window membrane; d: day, h: hour; O: no effect; P/PP/PPP: partial, not significant/partial and statistically significant/complete \& statistically significant protection; T/TT/TTT: partial, not significant/partial and statistically significant/complete \& statistically significant rescue.

\begin{tabular}{|c|c|c|c|c|}
\hline Therapy (dose) & Aminoglycoside (dose) & Species & Outcome & Reference \\
\hline $\begin{array}{l}\text { Dihydroxybenzoate }(100 \mathrm{mg} / \mathrm{kg}, 1 \text { or } 2 \mathrm{x} / \mathrm{d} \text {, i.p., } \\
21 \text { or } 26 \mathrm{~d})\end{array}$ & $\begin{array}{l}\text { Gentamicin ( } 120 \mathrm{mg} / \mathrm{kg}, 1 \mathrm{x} / \mathrm{d} \text {, s.c., } 19 \mathrm{~d} \text { or } \\
135 \mathrm{mg} / \mathrm{kg}, 1 \text { x/d, s.c., } 14 \mathrm{~d})\end{array}$ & GP & $\mathrm{PP}$ & {$[196]$} \\
\hline $\begin{array}{l}\text { Deferoxamine }(100 \mathrm{mg} / \mathrm{kg}, 2 \mathrm{x} / \mathrm{d}, \text { s.c., } 28 \mathrm{~d}) \\
\text { Dihydroxybenzoate }(100 \mathrm{mg} / \mathrm{kg}, 1 \text { x/d, p.o. })\end{array}$ & Gentamicin $(120 \mathrm{mg} / \mathrm{kg}, 1$ x/d, s.c., $19 \mathrm{~d})$ & GP & $\begin{array}{l}\mathrm{PP} \\
\mathrm{PP}\end{array}$ & {$[197]$} \\
\hline Dihydroxybenzoate $(300 \mathrm{mg} / \mathrm{kg}, 2 \mathrm{x} / \mathrm{d}, 14-15 \mathrm{~d})$ & Kanamycin $(400-900$ mg/kg, 2 x/d, s.c., 15 d) & $\mathrm{M}, \mathrm{Y}$ & PP & {$[198]$} \\
\hline Aspirin $(0.1$ or $1.0 \mathrm{mg} / \mathrm{mL}$ in drinking water, $8 \mathrm{~d})$ & Amikacin $(500 \mathrm{mg} / \mathrm{kg}, 1 \mathrm{x} / \mathrm{d}$, i.p., $5 \mathrm{~d})$ & $\mathrm{R}, \mathrm{Y}$ & PP & {$[199]$} \\
\hline Aspirin $(3 \times 500 \mathrm{mg} / \mathrm{d}$, p.o., $7 \mathrm{~d})$ & Gentamicin $(3 \times 80 \mathrm{mg} / \mathrm{d}$, i.v., $7 \mathrm{~d})$ & $\mathrm{H}$ & $\mathrm{PP}$ & {$[201]$} \\
\hline Aspirin $(3 \times 1 \mathrm{~g} / \mathrm{d}$, p.o., $14 \mathrm{~d})$ & Gentamicin (total 975-986 mg i.v./patient) & $\mathrm{H}$ & PPP & {$[202]$} \\
\hline Aspirin $(3 \times 1 \mathrm{~g} / \mathrm{d}$, p.o., $14 \mathrm{~d})$ & Gentamicin (80-160 mg, 2 x/d, i.v., 5-7 d) & $\mathrm{H}$ & $\mathrm{PP}$ & {$[203]$} \\
\hline NAC (600 mg, 2 x/d, p.o., $22-25 \mathrm{~d})$ & Gentamicin ( $2 \mathrm{mg} / \mathrm{kg} / \mathrm{d}$, i.v., avg. $15 \mathrm{~d})$ & $\mathrm{H}$ & PP & {$[210]$} \\
\hline D-Met (300 mg/kg/d, i.p., 28 d) & $\operatorname{Amikacin}(200$ mg/kg, 1 x/d, $28 \mathrm{~d})$ & GP, Y & PP & {$[211]$} \\
\hline D-Met $(200 \mathrm{mg} / \mathrm{kg}, 1-2 \mathrm{x} / \mathrm{d}$, s.c., $19 \mathrm{~d})$ & Gentamicin $(120 \mathrm{mg} / \mathrm{kg}, 1 \mathrm{x} / \mathrm{d}$, s.c., $19 \mathrm{~d})$ & GP, Y & PP & {$[212]$} \\
\hline L-NAME $(100 \mu \mathrm{M}, 4 \mathrm{~h})$ & & & PP & \\
\hline D-Met (50 mM, 4 h) & Gentamicin $(2 \mathrm{mg} / \mathrm{mL}, 4 \mathrm{~h})$ & GP, X & $\mathrm{PP}$ & {$[213]$} \\
\hline Leupeptin (1 mM, $4 \mathrm{~h})$ & & & $\mathrm{PP}$ & \\
\hline$\alpha$-LA (100 mg/kg/d, i.m., 15 d) & Amikacin (400 mg/kg, 1 x/d, i.m., 15 d) & GP, Y & $\mathrm{PP}$ & {$[214]$} \\
\hline Edaravone (3 mg/kg/d, i.p., 2-14 d) & Tobramycin $(160 \mathrm{mg} / \mathrm{kg}, 1$ x/d, s.c., $14 \mathrm{~d})$ & $\mathrm{R}, \mathrm{Y}$ & PPP, TTT & {$[226]$} \\
\hline Resveratrol $(10 \mu \mathrm{M}$ or $100 \mu \mathrm{M}, 24 \mathrm{~h})$ & Gentamicin $(0.4 \mathrm{mM}, 24 \mathrm{~h})$ & $\mathrm{R}, \mathrm{X}$ & PP & {$[227]$} \\
\hline$\alpha$-Tocopherol (100 mg/kg, 1 x/d, i.m., 14 d) & Gentamicin $(100 \mathrm{mg} / \mathrm{kg}, 1$ x/d, i.m. $<14$ d) & GP, Y & $\mathrm{PP}$ & {$[216]$} \\
\hline$\alpha$-Tocopherol (100 mg/kg, 1 x/d, i.m., 14 d) & Gentamicin $(100 \mathrm{mg} / \mathrm{kg}, 1$ x/d, i.m. $<14 \mathrm{~d})$ & GP, Y & $\mathrm{PP}$ & {$[215]$} \\
\hline$\alpha$-Tocopherol (100 mg/kg, 1 x/d, i.m., $14 \mathrm{~d})$ & Gentamicin $(100 \mathrm{mg} / \mathrm{kg}, 1 \mathrm{x} / \mathrm{d}, \mathrm{i} . \mathrm{m} .<14 \mathrm{~d})$ & GP, Y & $\mathrm{PP}$ & {$[217]$} \\
\hline Glutathione (10 mM, $1 \mathrm{~h})$ & & & PP & \\
\hline Dithioerythritol (10 mM, $1 \mathrm{~h})$ & & & PP & \\
\hline Vitamin C (10 mM, $1 \mathrm{~h})$ & Gentamicin $(1 \mathrm{mM}, 1 \mathrm{~h})$ & GP, X & $\mathrm{PP}$ & {$[218]$} \\
\hline Trolox (4 mM, $1 \mathrm{~h})$ & & & $\mathrm{PP}$ & \\
\hline Phenylene Diamine (10 mM, $1 \mathrm{~h}$ ) & & & $\mathrm{PP}$ & \\
\hline Glutathione (0.6 mL 0.3 M, p.o., $14 \mathrm{~d}$ ) & Gentamicin $(100 \mathrm{mg} / \mathrm{kg}, 1$ x/d, i.m., $14 \mathrm{~d})$ & GP, Y & $\mathrm{PP}$ & {$[228]$} \\
\hline $\begin{array}{l}\text { Ginkgo biloba }(10 \mathrm{mg} / \mathrm{kg}, 30 \mathrm{~min} \text { to } \mathrm{RWM} \text { or } \\
1 \times 100 \mathrm{mg} / \mathrm{kg} \text { i.p. })\end{array}$ & $\begin{array}{l}\text { Gentamicin }(5 \mathrm{mg} / \mathrm{kg}, 45 \mathrm{~min} \text { to } \mathrm{RWM} \text { or } \\
5 \mathrm{mg} / \mathrm{kg}, 24 \mathrm{~h} \text { to RWM })\end{array}$ & GP, Y & $\mathrm{P}$ & {$[219]$} \\
\hline Danshen $(1-20 \mathrm{mg} / \mathrm{kg}, 2 \mathrm{x} / \mathrm{d}$, s.c., $15 \mathrm{~d})$ & Kanamycin $(700 \mathrm{mg} / \mathrm{kg}, 2 \mathrm{x} / \mathrm{d}$, s.c., $15 \mathrm{~d})$ & $\mathrm{M}, \mathrm{Y}$ & PP & {$[220]$} \\
\hline $\begin{array}{l}\text { Melatonin }(10 \mathrm{mg} / \mathrm{L} \text { in drinking water p.o., } 12 \mathrm{~d} \\
\text { or } 250 \mu \mathrm{g} \text {, s.c., } 1 \mathrm{x} / \mathrm{d}, 5-12 \mathrm{~d})\end{array}$ & $\begin{array}{l}\text { Gentamicin }(160 \mathrm{mg} / \mathrm{kg}, 1 \mathrm{x} / \mathrm{d} \text {, i.m., } 5 \mathrm{~d}) \\
\text { Tobramycin }(200 \mathrm{mg} / \mathrm{kg}, 1 \mathrm{x} / \mathrm{d} \text {, i.m., } 5 \mathrm{~d})\end{array}$ & $\mathrm{R}, \mathrm{Y}$ & $\mathrm{PP}$ & {$[223]$} \\
\hline Melatonin $(0.4$ or $4.0 \mathrm{mg} / \mathrm{kg}, 1 \mathrm{x} /$ d, i.p., $14 \mathrm{~d})$ & Amikacin (600 mg/kg, 1 x/d, i.m., 14 d) & $\mathrm{R}, \mathrm{Y}$ & $\mathrm{P}(0,4 \mathrm{mg})$ & {$[221]$} \\
\hline Melatonin $(0.31 / \mathrm{kg}, 1$ x/d, i.m., $17 \mathrm{~d})$ & Gentamicin $(120 \mathrm{mg} / \mathrm{kg}, 1$ x/d, i.m., $17 \mathrm{~d})$ & $\begin{array}{l}\mathrm{GP}, \mathrm{X}+ \\
\mathrm{Y}\end{array}$ & $\mathrm{PP}$ & {$[222]$} \\
\hline Melatonin $(10,50,100 \mu \mathrm{M}, 1-7 \mathrm{~d})$ & Gentamicin (1 mM, $48 \mathrm{~h})$ & $\mathrm{R}, \mathrm{X}$ & $\mathrm{PP}$ & {$[175]$} \\
\hline M40403 (30 $\mu \mathrm{M}, 24 \mathrm{~h})$ & Gentamicin $(0.5$ or $1 \mathrm{mM}, 24 \mathrm{~h})$ & $\mathrm{M}, \mathrm{X}$ & $\mathrm{PP}$ & {$[225]$} \\
\hline $\mathrm{Cu} / \mathrm{Zn} \mathrm{SOD}$, transgenic & Kanamycin $(400 \mathrm{mg} / \mathrm{kg}$, s.c., $10 \mathrm{~d})$ & $\mathrm{M}, \mathrm{Y}$ & $\mathrm{PP}$ & [209] \\
\hline $\begin{array}{l}\mathrm{Cu} / \mathrm{Zn} \mathrm{SOD} \text {, transgenic } \\
\text { Mn SOD, transgenic }\end{array}$ & $\begin{array}{l}\text { Kanamycin ( } 250 \mathrm{mg} / \mathrm{kg} \text {, s.c., single dose) } \\
\text { Ethacrynic Acid ( } 40 \mathrm{mg} / \mathrm{kg} \text {, i.v., single dose) }\end{array}$ & GP, Y & $\begin{array}{l}\mathrm{O}(\mathrm{Cu} / \mathrm{Zn}) \\
\mathrm{PP}(\mathrm{Mn})\end{array}$ & {$[224]$} \\
\hline
\end{tabular}

channel block has to be temporary. MET channel blockers have been tested successfully in vitro [104]. Yet their in vivo effects are largely unknown. The second possibility of preventing AG entry through the MET channel involves steric modification of the chemical structure of AGs. From electrophysiological measurements, the narrowest part of the MET channel pore has been estimated to be $1.25 \mathrm{~nm}$ [104]. As dihydrostreptomycin is capable of blocking the MET channel [92], the difference in the dimensions of the MET channel and certain AGs appears to be small. Therefore, 
TABle 3: Overview of studies with alternative strategies to protect from aminoglycoside ototoxicity. C: Chicken, $\mathrm{CH}$ : Chinchilla, G: Gerbil, GP: Guinea Pig, M: Mouse, R: Rat, X: in vitro, Y: in vivo; i.m.: intramuscular, i.v.: intravenous, i.p.: intraperitoneal, i.t.: intratympanic, s.c.: subcutaneous; d: day, h: hour, q12 h: every 12 h; O: no effect; P/PP/PPP: partial, not significant/partial and statistically significant/complete and statistically significant protection.

\begin{tabular}{|c|c|c|c|c|}
\hline Therapy (dose) & Aminoglycoside (dose) & Species & Outcome & Reference \\
\hline $\mathrm{BDNF}(10 \mathrm{ng} / \mathrm{mL}, 4 \mathrm{~h})$ & Gentamicin $(2 \mathrm{mg} / \mathrm{mL}, 4 \mathrm{~h})$ & GP, X & $\mathrm{PP}$ & {$[213]$} \\
\hline $\begin{array}{l}\text { Dizocilpine }(1 \mathrm{mg} / \mathrm{kg} / \mathrm{d} \text {, osmotic } \\
\text { pump, } 14 \mathrm{~d}) \\
\text { Ifenprodil }(10 \mathrm{mg} / \mathrm{kg} / \mathrm{d} \text {, osmotic } \\
\text { pump, } 14 \mathrm{~d})\end{array}$ & $\begin{array}{l}\text { Neomycin }(50 \mathrm{mg} / \mathrm{kg}, 1 \mathrm{x} / \mathrm{d} \text {, s.c., } 14 \mathrm{~d}) \text { or } \\
\text { Kanamycin }(250 \mathrm{mg} / \mathrm{kg}, 1 \mathrm{x} / \mathrm{d} \text {, s.c., } 21 \mathrm{~d})\end{array}$ & GP, Y & $\begin{array}{l}\mathrm{PP} \\
\mathrm{PP}\end{array}$ & {$[233]$} \\
\hline Dizocilpine (1 mg/kg, 1 x/d, s.c.,10 d) & Streptomycin $(400 \mathrm{mg} / \mathrm{kg}, 1 \mathrm{x} / \mathrm{d}$, s.c., $10 \mathrm{~d})$ & $\mathrm{R}, \mathrm{Y}$ & $\mathrm{PP}$ & {$[234]$} \\
\hline CTNF (0.44 g/kg, 1 x/d, s.c., 30 d) & Gentamicin ( $80 \mathrm{mg} / \mathrm{kg}, 1 \mathrm{x} / \mathrm{d}$, i.m., $30 \mathrm{~d})$ & GP, Y & $\mathrm{PP}$ & [249] \\
\hline $\begin{array}{l}\text { BDNF ( } 1 \mu \mathrm{g} \text {, pellet in semicircular } \\
\text { canal, with AG or } 1 \text { week later, over } \\
1-8 \text { weeks) }\end{array}$ & $\begin{array}{l}\text { Gentamicin }(50 \mu \mathrm{g} \text {, pellet in semicircular canal, over } \\
1-8 \text { weeks })\end{array}$ & $\mathrm{CH}, \mathrm{Y}$ & $\begin{array}{c}\mathrm{P} \\
\mathrm{TT}\end{array}$ & {$[246]$} \\
\hline $\begin{array}{l}\text { BDNF }(100 \mu \mathrm{g} / \mathrm{mL}, \text { local, pump @ } \\
0.25 \mu \mathrm{L} / \mathrm{h}, 30 \mathrm{~d}) \\
\text { NT-3 }(100 \mu \mathrm{g} / \mathrm{mL}, \text { local, pump @ } \\
0.25 \mu \mathrm{L} / \mathrm{h}, 30 \mathrm{~d})\end{array}$ & Kanamycin (400 mg/kg, 1 x/d, i.p., 5 d) & GP, Y & $\begin{array}{l}\mathrm{O}(\mathrm{BDNF}) \\
\mathrm{PP}(\mathrm{NT}-3)\end{array}$ & {$[248]$} \\
\hline $\begin{array}{l}\text { L-NAME }(100 \mu \mathrm{M}, 8 \mathrm{~h}) \\
\text { BDNF }(10 \mathrm{ng} / \mathrm{mL}, 8 \mathrm{~h})\end{array}$ & Gentamicin $(2 \mathrm{mg} / \mathrm{mL}, 8 \mathrm{~h})$ & GP, X & $\begin{array}{l}\mathrm{PP} \\
\mathrm{PP}\end{array}$ & {$[247]$} \\
\hline Isosorbide ( $1 \mathrm{mM}, 8 \mathrm{~h})$ & Gentamicin $(2 \mathrm{mg} / \mathrm{mL}, 8 \mathrm{~h})$ & GP, X & $\mathrm{PP}$ & {$[255]$} \\
\hline $\begin{array}{l}\text { MK } 801(1 \mathrm{mg} / \mathrm{kg}, 3 \mathrm{x} \text { before pump } \\
\text { implantation })+/-\mathrm{NT}-3 \text { (local in } \\
\text { pump @ } 300 \mathrm{ng} / \mathrm{h} \text { over } 14 \mathrm{~d})\end{array}$ & Amikacin (300 mM, local pump @ $5 \mu \mathrm{L} / \mathrm{h}, 24 \mathrm{~h}$ ) & GP, Y & $\begin{array}{l}\mathrm{P}(\mathrm{MK} 801) \\
\mathrm{PP}(\mathrm{MK}+ \\
\mathrm{NT})\end{array}$ & {$[256]$} \\
\hline GDNF $(10 \mu \mathrm{M}, 72-96 \mathrm{~h})$ & Neomycin $(0.6 \mathrm{mM}, 72 \mathrm{~h})$ & $\mathrm{R}, \mathrm{X}$ & $\mathrm{P}(\mathrm{X})$ & \\
\hline $\begin{array}{l}\text { GDNF }(50 \mathrm{ng} / \mathrm{mL} \text {, local pump @ } \\
0.5 \mu \mathrm{L} / \mathrm{h} \text { or single dose } 0.1 \mathrm{mg} \text {, i.t. })\end{array}$ & $\begin{array}{l}\text { Kanamycin ( } 200 \mathrm{mg} / \mathrm{kg} \text {, s.c., single dose })+ \text { Ethacrynic } \\
\text { Acid ( } 40 \mathrm{mg} / \mathrm{kg} \text {, i.v., single dose })\end{array}$ & GP, Y & $\mathrm{PP}(\mathrm{Y})$ & {$[250]$} \\
\hline GDNF + TGF-1, transgenic & $\begin{array}{l}\text { Kanamycin ( } 150 \mathrm{mg} / \mathrm{kg} \text {, s.c., single dose })+ \text { Ethacrynic } \\
\text { Acid ( } 40 \mathrm{mg} / \mathrm{kg} \text {, i.v., single dose })\end{array}$ & GP, Y & $\mathrm{PP}$ & {$[257]$} \\
\hline GDNF, transgenic & Gentamicin ( $8 \mathrm{mg}$, i.t., single dose) & GP, Y & PP & {$[258]$} \\
\hline GDNF, transgenic & $\begin{array}{l}\text { Kanamycin ( } 200 \mathrm{mg} / \mathrm{kg} \text {, s.c., single dose })+ \text { Ethacrynic } \\
\text { Acid ( } 40 \mathrm{mg} / \mathrm{kg} \text {, i.v., single dose })\end{array}$ & GP, Y & $\mathrm{PP}$ & [259] \\
\hline $\begin{array}{l}\text { Gentamicin }(10 \mathrm{mg} / \mathrm{kg}, 1 \mathrm{x} / \mathrm{d} \text {, i.m., } \\
30 \mathrm{~d})\end{array}$ & Gentamicin $(160 \mathrm{mg} / \mathrm{kg}, 1 \mathrm{x} / \mathrm{d}$, i.m., $10 \mathrm{~d})$ & GP, Y & PP & {$[230]$} \\
\hline Amikacin $(20$ mg/kg, 1 x/d, i.m., $30 \mathrm{~d})$ & Amikacin $(400$ mg/kg, 1 x/d, i.m., 10 d) & GP, Y & $\mathrm{PP}$ & {$[231]$} \\
\hline $\begin{array}{l}2 \text { Octave-band noise ( } 81 \mathrm{~dB} \text { SPL for } \\
21 \mathrm{~d})\end{array}$ & Gentamicin $(445 \mu \mathrm{g}$, local to RWM over $14 \mathrm{~d})$ & $\mathrm{G}, \mathrm{Y}$ & $\mathrm{P}$ & [232] \\
\hline $\begin{array}{l}\text { Ethacrynic Acid ( } 40 \mathrm{mg} / \mathrm{kg} \text {, i.v., single } \\
\text { dose, } 12-18 \mathrm{~h})\end{array}$ & Gentamicin (125 mg/kg, 1-20 injections q12h, i.m.) & GP, Y & $\mathrm{PP}$ & {$[252]$} \\
\hline
\end{tabular}

widening of the AG diameter by binding of inert molecules on sites irrelevant for antimicrobial activity appears a promising strategy to prohibit passage of AGs through the MET channel into the hair cells. As the passage through the bacterial membrane is self-promoting and depends on the relative positive charge of the AG [42-47, 262-264], the intended increase of size should not affect bacterial uptake of the AG as long as the polarity and the charge of the new AG molecule remains the same. However, interference with the antimicrobial activity due to sterical impairment of binding to the bacterial ribosome needs to be tested.

Another target lies in preventing AG from entering the inner ear fluids. AGs enter the inner ear fluids through the stria vascularis [87]. Blocking the passage of AG requires the identification of the transport mechanism in the bloodlabyrinth barrier.

AGs are potent antibiotics with limited application due to their side effects. Until the problem of AG ototoxicity is solved, it is crucial to be judicious in prescribing AGs for defined clinical indications. Furthermore, it is important for clinicians to remember the genetic mutations as a cause for increased susceptibility to ototoxic damage. However, indiscriminate genetic screening is not cost-effective at present. Instead, a thorough history of the patient and their family regarding ototoxic symptoms from antibiotics helps assessing the individual risk. Independent from genetic mutations, patients should undergo a baseline hearing test including ultrahigh frequencies prior to AG administration 
to allow for early and unambiguous assessment of potential ototoxic damage.

\section{Acknowledgments}

M. E. Huth is supported by the Swiss National Science Foundation (Fellowships for prospective researchers; PBSKP3_130635/1). A. J. Ricci and A. G. Cheng are supported by the National Institutes of Health, NIDCD RO1 DC003896, R21 DC012183, K08 DC011043, and internal funding via Stanford SPARK program.

\section{References}

[1] A. Schatz, E. Bugie, and S. A. Waksman, "Streptomycin, a substance exhibiting antibiotic activity against gram-positive and gram-negative bacteria," Proceedings of the Society for Experimental Biology and Medicine, vol. 55, pp. 66-69, 1944.

[2] S. Waksman, "Streptomycin: background, isolation, properties, and utilization," Nobel prize lecture, Nobel Organization, 1952, http://nobelprize.org/nobel_prizes/medicine/ laureates/1952/waksman-lecture.pdf.

[3] H. Umezawa et al., "Production and isolation of a new antibiotic: kanamycin," The Journal of Antibiotics, vol. 10, no. 5, pp. 181-188, 1957.

[4] S. A. Waksman and H. A. Lechevalier, "Neomycin, a new antibiotic active against streptomycin-resistant bacteria, including tuberculosis organisms," Science, vol. 109, no. 2830, pp. 305-307, 1949.

[5] M. J. Weinstein, G. M. Luedemann, E. M. Oden et al., "Gentamicin, a new antibiotic complex from Micromonospora," Journal of Medicinal Chemistry, vol. 6, no. 4, pp. 463-464, 1963.

[6] H. Kawaguchi, "Discovery, chemistry, and activity of amikacin," Journal of Infectious Diseases, vol. 134, supplement, pp. S242-S248, 1976.

[7] R. H. Drew, "Aminoglycosides," 2011, http://www.uptodate. com.

[8] R. Hock and R. J. Anderson, "Prevention of drug-induced nephrotoxicity in the intensive care unit," Journal of Critical Care, vol. 10, no. 1, pp. 33-43, 1995.

[9] G. Toubeau, G. Laurent, and M. B. Carlier, "Tissue repair in rat kidney cortex after short treatment with aminoglycosides at low doses. A comparative biochemical and morphometric study," Laboratory Investigation, vol. 54, no. 4, pp. 385-393, 1986.

[10] G. J. Greenwood, "Neomycin ototoxicity; report of a case," A.M.A. Archives of Otolaryngology, vol. 69, no. 4, pp. 390$397,1959$.

[11] R. A. Hettig and J. D. Adcock, "Studies on the toxicity of streptomycin for man: a preliminary report," Science, vol. 103, no. 2673, pp. 355-357, 1946.

[12] H. C. Hinshaw, W. H. Feldman, and K. H. Pfuetze, "Treatment of tuberculosis with streptomycin; a summary of observations on one hundred cases," Journal of the American Medical Association, vol. 132, no. 13, pp. 778-782, 1946.

[13] G. Matz, L. Rybak, P. S. Roland et al., "Ototoxicity of ototopical antibiotic drops in humans," OtolaryngologyHead and Neck Surgery, vol. 130, no. 3, pp. S79-S82, 2004.

[14] M. D. Rizzi and K. Hirose, "Aminoglycoside ototoxicity," Current Opinion in Otolaryngology and Head and Neck Surgery, vol. 15, no. 5, pp. 352-357, 2007.
[15] G. J. Matz, "Aminoglycoside cochlear ototoxicity," Otolaryngologic Clinics of North America, vol. 26, no. 5, pp. 705-712, 1993.

[16] W. E. Heck, H. C. Hinshaw, and H. G. Parsons, "Auditory ototoxicity in tuberculosis patients treated with a report of the incidence of hearing loss in a series of 1,150 cases," Journal of the American Medical Association, vol. 86, pp. 18-20, 1963.

[17] W. E. Fee, "Aminoglycoside ototoxicity in the human," Laryngoscope, vol. 90, no. 10, pp. 1-19, 1980.

[18] M. Mulheran, C. Degg, S. Burr, D. W. Morgan, and D. E. Stableforth, "Occurrence and risk of cochleotoxicity in cystic fibrosis patients receiving repeated high-dose aminoglycoside therapy," Antimicrobial Agents and Chemotherapy, vol. 45, no. 9, pp. 2502-2509, 2001.

[19] L. P. Rybak and J. Schacht, "Drug-induced hearing loss," in Auditory Trauma, Protection and Repair, P. A. Schacht and R. R. Fay, Eds., pp. 219-256, Springer, New York, NY, USA, 2008.

[20] J. M. Aran and J. Darrouzet, "Observation of click evoked compound VIII nerve responses before, during, and over seven months after kanamycin treatment in the guinea pig," Acta Oto-Laryngologica, vol. 79, no. 1-2, pp. 24-32, 1975.

[21] J. E. Hawkins and L.G. Johnson, "Histopathology of cochlear and vestibular ototoxicity in laboratory animals," in Aminoglycoside Ototoxicity, S. A. Lerner, G. J. Matz, and J. E. Hawkins, Eds., pp. 327-339, Little \& Brown, Boston, Mass, USA, 1981.

[22] S. A. Fausti, J. A. Henry, H. I. Schaffer, D. J. Olson, R. H. Frey, and W. J. McDonald, "High-frequency audiometric monitoring for early detection of aminoglycoside ototoxicity," Journal of Infectious Diseases, vol. 165, no. 6, pp. 1026-1032, 1992.

[23] L. A. Grohskopf, W. C. Huskins, R. L. Sinkowitz-Cochran, G. L. Levine, D. A. Goldmann, and W. R. Jarvis, "Use of antimicrobial agents in United States neonatal and pediatric intensive care patients," Pediatric Infectious Disease Journal, vol. 24, no. 9, pp. 766-773, 2005.

[24] K. E. Price, "Aminoglycoside research 1975-1985: prospects for development of improved agents," Antimicrobial Agents and Chemotherapy, vol. 29, no. 4, pp. 543-548, 1986.

[25] E. Durante-Mangoni, A. Grammatikos, R. Utili, and M. E. Falagas, "Do we still need the aminoglycosides?" International Journal of Antimicrobial Agents, vol. 33, no. 3, pp. 201205, 2009.

[26] J. A. Caminero, G. Sotgiu, A. Zumla, and G. B. Migliori, "Best drug treatment for multidrug-resistant and extensively drugresistant tuberculosis," The Lancet Infectious Diseases, vol. 10, no. 9, pp. 621-629, 2010.

[27] G. M. Pacifici, "Clinical pharmacokinetics of aminoglycosides in the neonate: a review," European Journal of Clinical Pharmacology, vol. 65, no. 4, pp. 419-427, 2009.

[28] J. Schacht, "Biochemical basis of aminoglycoside ototoxicity," Otolaryngologic Clinics of North America, vol. 26, no. 5, pp. 845-856, 1993.

[29] P. J. L. Daniels, A. K. Mallams, J. Weinstein, J. J. Wright, and G. W. A. Milne, "Mass spectral studies on aminocyclitolaminoglycoside antibiotics," Journal of the Chemical Society, Perkin Transactions 1, no. 10, pp. 1078-1088, 1976.

[30] P. D. Damper and W. Epstein, "Role of the membrane potential in bacterial resistance to aminoglycoside antibiotics," Antimicrobial Agents and Chemotherapy, vol. 20, no. 6, pp. 803-808, 1981.

[31] S. Jana and J. K. Deb, "Molecular understanding of aminoglycoside action and resistance," Applied Microbiology and Biotechnology, vol. 70, no. 2, pp. 140-150, 2006. 
[32] J. G. Silva and I. Carvalho, "New insights into aminoglycoside antibiotics and derivatives," Current Medicinal Chemistry, vol. 14, no. 10, pp. 1101-1119, 2007.

[33] R. Garraffo, H. B. Drugeon, P. Dellamonica, E. Bernard, and P. Lapalus, "Determination of optimal dosage regimen for amikacin in healthy volunteers by study of pharmacokinetics and bactericidal activity," Antimicrobial Agents and Chemotherapy, vol. 34, no. 4, pp. 614-621, 1990.

[34] A. I. Al-Amoud, B. J. Clark, and H. Chrystyn, "Determination of gentamicin in urine samples after inhalation by reversed-phase high-performance liquid chromatography using pre-column derivatisation with o-phthalaldehyde," Journal of Chromatography B, vol. 769, no. 1, pp. 89-95, 2002.

[35] K. G. Naber, S. R. Westenfelder, and P. O. Madsen, "Pharmacokinetics of the aminoglycoside antibiotic tobramycin in humans," Antimicrobial Agents and Chemotherapy, vol. 3, no. 4, pp. 469-473, 1973.

[36] J. M. Walker, R. Wise, and M. Mitchard, "The pharmacokinetics of amikacin and gentamicin in volunteers: a comparison of individual differences," Journal of Antimicrobial Chemotherapy, vol. 5, no. 1, pp. 95-99, 1979.

[37] D. S. Hoff, R. A. Wilcox, L. M. Tollefson, P. G. Lipnik, A. R. Commers, and M. Liu, "Pharmacokinetic outcomes of a simplified, weight-based, extended-interval gentamicin dosing protocol in critically ill neonates," Pharmacotherapy, vol. 29, no. 11, pp. 1297-1305, 2009.

[38] C. R. Kumana and K. H. Yuen, "Parenteral aminoglycoside therapy: selection, administration and monitoring," Drugs, vol. 47, no. 6, pp. 902-913, 1994.

[39] L. D. Sabath and I. Toftegaard, "Rapid microassays for clindamycin and gentamicin when present together and the effect of $\mathrm{pH}$ and of each on the antibacterial activity of the other," Antimicrobial agents and chemotherapy, vol. 6, no. 1, pp. 54-59, 1974.

[40] A. Hinz et al., "Membrane proteases and aminoglycoside antibiotic resistance," The Journal of Bacteriology, vol. 139, no. 18, pp. 4790-4797, 2011.

[41] E. P. Abraham and E. S. Duthie, "Effect of $\mathrm{pH}$ of the medium on activity of streptomycin and penicillin and other chemotherapeutic substances," The Lancet, vol. 247, no. 6396, pp. 455-459, 1946.

[42] R. E. W. Hancock, S. W. Farmer, Z. Li, and K. Poole, "Interaction of aminoglycosides with the outer membranes and purified lipopolysaccharide and OmpF porin of Escherichia coli," Antimicrobial Agents and Chemotherapy, vol. 35, no. 7, pp. 1309-1314, 1991.

[43] A. A. Peterson, R. E. W. Hancock, and E. J. McGroarty, "Binding of polycationic antibiotics and polyamines to lipopolysaccharides of Pseudomonas aeruginosa," Journal of Bacteriology, vol. 164, no. 3, pp. 1256-1261, 1985.

[44] P. R. G. Schindler and M. Teuber, "Action of polymyxin $\mathrm{B}$ on bacterial membranes: morphological changes in the cytoplasm and in the outer membrane of Salmonella typhimurium and Escherichia coli B," Antimicrobial Agents and Chemotherapy, vol. 8, no. 1, pp. 95-104, 1975.

[45] N. L. Martin and T. J. Beveridge, "Gentamicin interaction with Pseudomonas aeruginosa cell envelope," Antimicrobial Agents and Chemotherapy, vol. 29, no. 6, pp. 1079-1087, 1986.

[46] J. L. Kadurugamuwa, J. S. Lam, and T. J. Beveridge, "Interaction of gentamicin with the A band and B band lipopolysaccharides of Pseudomonas aeruginosa and its possible lethal effect," Antimicrobial Agents and Chemotherapy, vol. 37, no. 4, pp. 715-721, 1993.
[47] L. E. Bryan and H. M. Van Den Elzen, "Effects of membraneenergy mutations and cations on streptomycin and gentamicin accumulation by bacteria: a model for entry of streptomycin and gentamicin in susceptible and resistant bacteria," Antimicrobial Agents and Chemotherapy, vol. 12, no. 2, pp. 163-177, 1977.

[48] E. C. Cox, J. R. White, and J. G. Flaks, "Streptomycin action and the ribosome," Proceedings of the National Academy of Sciences of the United States of America, vol. 51, pp. 703-709, 1964.

[49] J. Davies, P. Anderson, and B. D. Davis, "Inhibition of protein synthesis by spectinomycin," Science, vol. 149, no. 3688, pp. 1096-1098, 1965.

[50] L. E. Bryan and S. Kwan, "Roles of ribosomal binding, membrane potential, and electron transport in bacterial upake of streptomycin and gentamicin," Antimicrobial Agents and Chemotherapy, vol. 23, no. 6, pp. 835-845, 1983.

[51] R. Green and H. F. Noller, "Ribosomes and translation," Annual Review of Biochemistry, vol. 66, pp. 679-716, 1997.

[52] R. T. Garvin, D. K. Biswas, and L. Gorini, "The effects of streptomycin or dihydrostreptomycin binding to 16S RNA or to 30 S ribosomal subunits," Proceedings of the National Academy of Sciences of the United States of America, vol. 71, no. 10, pp. 3814-3818, 1974.

[53] J. Davies and B. D. Davis, "Misreading of ribonucleic acid code words induced by aminoglycoside antibiotics. The effect of drug concentration," Journal of Biological Chemistry, vol. 243, no. 12, pp. 3312-3316, 1968.

[54] M. J. Cabanas, D. Vazquez, and J. Modolell, "Inhibition of ribosomal translocation by aminoglycoside antibiotics," Biochemical and Biophysical Research Communications, vol. 83, no. 3, pp. 991-997, 1978.

[55] M. Misumi, T. Nishimura, T. Komai, and N. Tanaka, "Interaction of kanamycin and related antibiotics with the large subunit of ribosomes and the inhibition of translocation," Biochemical and Biophysical Research Communications, vol. 84, no. 2, pp. 358-365, 1978.

[56] K. Fredrick and H. F. Noller, "Catalysis of ribosomal translocation by sparsomycin," Science, vol. 300, no. 5622, pp. 1159-1162, 2003.

[57] M. B. Feldman, D. S. Terry, R. B. Altman, and S. C. Blanchard, "Aminoglycoside activity observed on single pre-translocation ribosome complexes.," Nature Chemical Biology, vol. 6, no. 1, pp. 54-62, 2010.

[58] D. Fourmy, M. I. Recht, and J. D. Puglisi, "Binding of neomycin-class aminoglycoside antibiotics to the A-site of 16 S rRNA," Journal of Molecular Biology, vol. 277, no. 2, pp. 347-362, 1998.

[59] H. F. Noller, "Ribosomal RNA and translation," Annual Review of Biochemistry, vol. 60, pp. 191-227, 1991.

[60] A. R. Smyth and J. Bhatt, "Once-daily versus multiple-daily dosing with intravenous aminoglycosides for cystic fibrosis," Cochrane database of systematic reviews (Online), vol. 1, article CD002009, 2010.

[61] N. Fischel-Ghodsian, "Genetic factors in aminoglycoside toxicity," Pharmacogenomics, vol. 6, no. 1, pp. 27-36, 2005.

[62] D. N. Hu, W. Q. Qiu, B. T. Wu et al., "Genetic aspects of antibiotic induced deafness: mitochondrial inheritance," Journal of Medical Genetics, vol. 28, no. 2, pp. 79-83, 1991.

[63] T. Hutchin, I. Haworth, K. Higashi et al., "A molecular basis for human hypersensitivity to aminoglycoside antibiotics," Nucleic Acids Research, vol. 21, no. 18, pp. 4174-4179, 1993.

[64] E. Ruiz-Pesini and D. C. Wallace, "Evidence for adaptive selection acting on the tRNA and rRNA genes of human 
mitochondrial DNA," Human Mutation, vol. 27, no. 11, pp. 1072-1081, 2006.

[65] T. R. Prezant, J. V. Agapian, M. C. Bohlman et al., "Mitochondrial ribosomal RNA mutation associated with both antibiotic- induced and non-syndromic deafness," Nature Genetics, vol. 4, no. 3, pp. 289-294, 1993.

[66] H. Zhao, R. Li, Q. Wang et al., "Maternally inherited aminoglycoside-induced and nonsyndromic deafness is associated with the novel C1494T mutation in the mitochondrial $12 \mathrm{~S}$ rRNa gene in a large Chinese family," American Journal of Human Genetics, vol. 74, no. 1, pp. 139-152, 2004.

[67] M. Li and A. Tzagoloff, "Identification of the paromomycinresistance mutation in the $15 \mathrm{~S}$ rRNA gene of yeast mitochondria," Journal of Biological Chemistry, vol. 257, no. 10, pp. 5921-5928, 1982.

[68] E. A. Spangler and E. H. Blackburn, "The nucleotide sequence of the $17 \mathrm{~S}$ ribosomal RNA gene of Tetrahymena thermophila and the identification of point mutations resulting in resistance to the antibiotics paromomycin and hygromycin," Journal of Biological Chemistry, vol. 260, no. 10, pp. 6334-6340, 1985.

[69] S. N. Hobbie, S. Akshay, S. K. Kalapala, C. M. Bruell, D. Shcherbakov, and E. C. Böttger, "Genetic analysis of interactions with eukaryotic rRNA identify the mitoribosome as target in aminoglycoside ototoxicity," Proceedings of the National Academy of Sciences of the United States of America, vol. 105, no. 52, pp. 20888-20893, 2008.

[70] K. Hamasaki and R. R. Rando, "Specific binding of aminoglycosides to a human rRNA construct based on a DNA polymorphism which causes aminoglycoside-induced deafness," Biochemistry, vol. 36, no. 40, pp. 12323-12328, 1997.

[71] G. E. Hyde, "Mitochondrial role in hair cell survival after injury," Otolaryngology — Head and Neck Surgery, vol. 113, no. 5, pp. 530-540, 1995.

[72] K. N. Owens, D. E. Cunningham, G. Macdonald, E. W. Rubel, D. W. Raible, and R. Pujol, "Ultrastructural analysis of aminoglycoside-induced hair cell death in the zebrafish lateral line reveals an early mitochondrial response," Journal of Comparative Neurology, vol. 502, no. 4, pp. 522-543, 2007.

[73] M. L. Avent et al., "Current use of aminoglycosides: indications, pharmacokinetics and monitoring for toxicity," Internal Medicine Journal, vol. 41, no. 6, pp. 441-449, 2011.

[74] M. Bitner-Glindzicz, M. Pembrey, A. Duncan et al., "Prevalence of mitochondrial $1555 \mathrm{~A} \rightarrow \mathrm{G}$ mutation in European children," The New England Journal of Medicine, vol. 360, no. 6, pp. 640-642, 2009.

[75] J. Chen, L. Yang, A. Yang et al., "Maternally inherited aminoglycoside-induced and nonsyndromic hearing loss is associated with the 12S rRNA C1494T mutation in three Han Chinese pedigrees," Gene, vol. 401, no. 1-2, pp. 4-11, 2007.

[76] M. Ealy, K. A. Lynch, N. C. Meyer, and R. J.H. Smith, "The prevalence of mitochondrial mutations associated with aminoglycoside-induced sensorineural hearing loss in an NICU population," Laryngoscope, vol. 121, no. 6, pp. 11841186, 2011.

[77] Y. Zhu, Q. Li, Z. Chen et al., "Mitochondrial haplotype and phenotype of 13 Chinese families may suggest multioriginal evolution of mitochondrial C1494T mutation," Mitochondrion, vol. 9, no. 6, pp. 418-428, 2009.

[78] R. F. Johnson, A. P. Cohen, Y. Guo, K. Schibler, and J. H. Greinwald, "Genetic mutations and aminoglycoside-induced ototoxicity in neonates," Otolaryngology-Head and Neck Surgery, vol. 142, no. 5, pp. 704-707, 2010.
[79] N. Fischel-Ghodsian, T. R. Prezant, X. Bu, and S. Oztas, "Mitochondrial ribosomal RNA gene mutation in a patient with sporadic aminoglycoside ototoxicity," American Journal of Otolaryngology —Head and Neck Medicine and Surgery, vol. 14, no. 6, pp. 399-403, 1993.

[80] R. A. M. S. Casano, D. F. Johnson, Y. Bykhovskaya, F. Torricelli, M. Bigozzi, and N. Fischel-Ghodsian, "Inherited susceptibility to aminoglycoside ototoxicity: genetic heterogeneity and clinical implications," American Journal of Otolaryngology-Head and Neck Medicine and Surgery, vol. 20, no. 3, pp. 151-156, 1999.

[81] T. Tono, K. Kiyomizu, K. Matsuda et al., "Different clinical characteristics of aminoglycoside-induced profound deafness with and without the $1555 \mathrm{~A} \rightarrow \mathrm{G}$ mitochondrial mutation," ORL, vol. 63, no. 1, pp. 25-30, 2001.

[82] G. Cortopassi and T. Hutchin, "A molecular and cellular hypothesis for aminoglycoside-induced deafness," Hearing Research, vol. 78, no. 1, pp. 27-30, 1994.

[83] J. R. Lindsay and R. Hinojosa, "Histopathologic features of the inner ear associated with Kearns Sayre syndrome," Archives of Otolaryngology, vol. 102, no. 12, pp. 747-752, 1976.

[84] A. Pandya, Nonsyndromic Hearing Loss and Deafness, Mitochondrial, 1993.

[85] G. Al-Malky et al., "Aminoglycoside antibiotics cochleotoxicity in paediatric cystic fibrosis (CF) patients: a study using extended high-frequency audiometry and distortion product otoacoustic emissions," International Journal of Audiology, vol. 50, no. 2, pp. 112-122, 2011.

[86] D. Dulon, J. M. Aran, G. Zajic, and J. Schacht, "Comparative uptake of gentamicin, netilmicin, and amikacin in the guinea pig cochlea and vestibule," Antimicrobial Agents and Chemotherapy, vol. 30, no. 1, pp. 96-100, 1986.

[87] Q. Wang and P. S. Steyger, "Trafficking of systemic fluorescent gentamicin into the cochlea and hair cells," Journal of the Association for Research in Otolaryngology, vol. 10, no. 2, pp. 205-219, 2009.

[88] S. Imaimura and J. C. Adams, "Distribution of gentamicin in the guinea pig inner ear after local or systemic application," Journal of the Association for Research in Otolaryngology, vol. 4, no. 2, pp. 176-195, 2003.

[89] P. Tran Ba Huy, P. Bernard, and J. Schacht, "Kinetics of gentamicin uptake and release in the rat. Comparison of inner ear tissues and fluids with other organs," Journal of Clinical Investigation, vol. 77, no. 5, pp. 1492-1500, 1986.

[90] E. Hashino and M. Shero, "Endocytosis of aminoglycoside antibiotics in sensory hair cells," Brain Research, vol. 704, no. 1, pp. 135-140, 1995.

[91] G. P. Richardson, A. Forge, C. J. Kros, J. Fleming, S. D. M. Brown, and K. P. Steel, "Myosin VIIA is required for aminoglycoside accumulation in cochlear hair cells," Journal of Neuroscience, vol. 17, no. 24, pp. 9506-9519, 1997.

[92] W. Marcotti, S. M. van Netten, and C. J. Kros, "The aminoglycoside antibiotic dihydrostreptomycin rapidly enters mouse outer hair cells through the mechano-electrical transducer channels," Journal of Physiology, vol. 567, no. 2, pp. 505-521, 2005.

[93] P. S. Steyger, S. L. Peters, J. Rehling, A. Hordichok, and C. F. Dai, "Uptake of gentamicin by bullfrog saccular hair cells in vitro," Journal of the Association for Research in Otolaryngology, vol. 4, no. 4, pp. 565-578, 2003.

[94] J. R. Waguespack and A. J. Ricci, "Aminoglycoside ototoxicity: permeant drugs cause permanent hair cell loss," Journal of Physiology, vol. 567, no. 2, pp. 359-360, 2005. 
[95] J. Darrouzet and A. Guilhaume, "Ototoxicité de la kanamycine au jour le jour. Étude expérimentale en microscopie électronique," Revue de Laryngologie Otologie Rhinologie, vol. 95, no. 9-10, pp. 601-621, 1974.

[96] T. Hasson, P. G. Gillespie, J. A. Garcia et al., "Unconventional myosins in inner-ear sensory epithelia," Journal of Cell Biology, vol. 137, no. 6, pp. 1287-1307, 1997.

[97] C. J. Kros, W. Marcotti, S. M. Van Netten et al., "Reduced climbing and increased slipping adaptation in cochlear hair cells of mice with Myo7a mutations," Nature Neuroscience, vol. 5, no. 1, pp. 41-47, 2002.

[98] Z. Mamdouh, M. C. Giocondi, R. Laprade, and C. Le Grimellec, "Temperature dependence of endocytosis in renal epithelial cells in culture," Biochimica et Biophysica Acta, vol. 1282, no. 2, pp. 171-173, 1996.

[99] S. E. Myrdal, K. C. Johnson, and P. S. Steyger, "Cytoplasmic and intra-nuclear binding of gentamicin does not require endocytosis," Hearing Research, vol. 204, no. 1-2, pp. 156$169,2005$.

[100] A. B. A. Kroese, A. Das, and A. J. Hudspeth, "Blockage of the transduction channels of hair cells in the bullfrog's sacculus by aminoglycoside antibiotics," Hearing Research, vol. 37, no. 3, pp. 203-218, 1989.

[101] A. Ricci, "Differences in mechano-transducer channel kinetics underlie tonotopic distribution of fast adaptation in auditory hair cells," Journal of Neurophysiology, vol. 87, no. 4, pp. 1738-1748, 2002.

[102] D. P. Corey and A. J. Hudspeth, "Ionic basis of the receptor potential in a vertebrate hair cell," Nature, vol. 281, no. 5733, pp. 675-677, 1979.

[103] J. E. Gale, W. Marcotti, H. J. Kennedy, C. J. Kros, and G. P. Richardson, "FM1-43 dye behaves as a permeant blocker of the hair-cell mechanotransducer channel," Journal of Neuroscience, vol. 21, no. 18, pp. 7013-7025, 2001.

[104] H. E. Farris, C. L. LeBlanc, J. Goswami, and A. J. Ricci, "Probing the pore of the auditory hair cell mechanotransducer channel in turtle," Journal of Physiology, vol. 558, no. 3, pp. 769-792, 2004.

[105] T. Hayashida, H. Hiel, D. Dulon, J. P. Erre, A. Guilhaume, and J. M. Aran, "Dynamic changes following combined treatment with gentamicin and ethacrynic acid with and without acoustic stimulation. Cellular uptake and functional correlates," Acta Oto-Laryngologica, vol. 108, no. 5-6, pp. 404-413, 1989.

[106] A. J. Ricci, H. J. Kennedy, A. C. Crawford, and R. Fettiplace, "The transduction channel filter in auditory hair cells," Journal of Neuroscience, vol. 25, no. 34, pp. 7831-7839, 2005.

[107] C. J. Kros, A. Rusch, and G. P. Richardson, "Mechanoelectrical transducer currents in hair cells of the cultured neonatal mouse cochlea," Proceedings of the Royal Society B, vol. 249, no. 1325, pp. 185-193, 1992.

[108] D. Z. Z. He, S. Jia, and P. Dallas, "Mechanoelectrical transduction of adult outer hair cells studied in a gerbil hemicochlea," Nature, vol. 429, no. 6993, pp. 766-770, 2004.

[109] A. J. Ricci, A. C. Crawford, and R. Fettiplace, "Tonotopic variation in the conductance of the hair cell mechanotransducer channel," Neuron, vol. 40, no. 5, pp. 983-990, 2003.

[110] J. Garcia-Anoveros and A. Duggan, TRPA1 in Auditory and Nociceptive Organs, 2007.

[111] Y. Asai, J. R. Holt, and G. S.G. Géléoc, "A quantitative analysis of the spatiotemporal pattern of transient receptor potential gene expression in the developing mouse cochlea," Journal of the Association for Research in Otolaryngology, vol. 11, no. 1, pp. 27-37, 2010.
[112] M. P. Cuajungco, C. Grimm, and S. Heller, "TRP channels as candidates for hearing and balance abnormalities in vertebrates," Biochimica et Biophysica Acta, vol. 1772, no. 8, pp. 1022-1027, 2007.

[113] P. S. Steyger, "Cellular uptake of aminoglycosides," Volta Review, vol. 105, no. 3, pp. 299-324, 2005.

[114] S. E. Myrdal and P. S. Steyger, "TRPV1 regulators mediate gentamicin penetration of cultured kidney cells," Hearing Research, vol. 204, no. 1-2, pp. 170-182, 2005.

[115] S. K. Moestrup, S. Cui, H. Vorum et al., "Evidence that epithelial glycoprotein 330/megalin mediates uptake of polybasic drugs," Journal of Clinical Investigation, vol. 96, no. 3, pp. 1404-1413, 1995.

[116] K. Mizuta, A. Saito, T. Watanabe et al., "Ultrastructural localization of megalin in the rat cochlear duct," Hearing Research, vol. 129, no. 1-2, pp. 83-91, 1999.

[117] J. Tauris, E. I. Christensen, A. Nykjær, C. Jacobsen, C. M. Petersen, and T. Ovesen, "Cubilin and megalin Co-localize in the neonatal inner ear," Audiology and Neurotology, vol. 14, no. 4, pp. 267-278, 2009.

[118] M. Lenoir and J. L. Puel, "Dose-dependent changes in the rat cochlea following aminoglycoside intoxidation. II. Histological study," Hearing Research, vol. 26, no. 2, pp. 199209, 1987.

[119] A. Forge, "Outer hair cell loss and supporting cell expansion following chronic gentamicin treatment," Hearing Research, vol. 19, no. 2, pp. 171-182, 1985.

[120] L. P. Rybak and C. A. Whitworth, "Ototoxicity: therapeutic opportunities," Drug Discovery Today, vol. 10, no. 19, pp. 1313-1321, 2005.

[121] R. N. Abi-Hachem, A. Zine, and T. R. Van de Water, "The injured cochlea as a target for inflammatory processes, initiation of cell death pathways and application of related otoprotective strategies," Recent Patents on CNS Drug Discovery, vol. 5, no. 2, pp. 147-163, 2010.

[122] E. M. Priuska and J. Schacht, "Formation of free radicals by gentamicin and iron and evidence for an iron/gentamicin complex," Biochemical Pharmacology, vol. 50, no. 11, pp. 1749-1752, 1995.

[123] W. J. Clerici, K. Hensley, D. L. DiMartino, and D. A. Butterfield, "Direct detection of ototoxicant-induced reactive oxygen species generation in cochlear explants," Hearing Research, vol. 98, no. 1-2, pp. 116-124, 1996.

[124] K. Hirose, D. M. Hockenbery, and E. W. Rubel, "Reactive oxygen species in chick hair cells after gentamicin exposure in vitro," Hearing Research, vol. 104, no. 1-2, pp. 1-14, 1997.

[125] S. H. Sha and J. Schacht, "Stimulation of free radical formation by aminoglycoside antibiotics," Hearing Research, vol. 128, no. 1-2, pp. 112-118, 1999.

[126] C. Thomas, M. M. Mackey, A. A. Diaz, and D. P. Cox, "Hydroxyl radical is produced via the Fenton reaction in submitochondrial particles under oxidative stress: implications for diseases associated with iron accumulation," Redox Report, vol. 14, no. 3, pp. 102-108, 2009.

[127] S. H. Sha and J. Schacht, "Formation of reactive oxygen species following bioactivation of gentamicin," Free Radical Biology and Medicine, vol. 26, no. 3-4, pp. 341-347, 1999.

[128] P. -W. Cheng, S. -H. Liu, Y. -H. Young, and S. -Y. Lin-Shiau, "D-Methionine attenuated cisplatin-induced vestibulotoxicity through altering ATPase activities and oxidative stress in guinea pigs," Toxicology and Applied Pharmacology, vol. 215, no. 2, pp. 228-236, 2006.

[129] P. W. Cheng, S. H. Liu, C. J. Hsu, and S. Y. Lin-Shiau, "Correlation of increased activities of $\mathrm{Na}+, \mathrm{K}+$-ATPase 
and $\mathrm{Ca} 2+-\mathrm{ATPase}$ with the reversal of cisplatin ototoxicity induced by D-methionine in guinea pigs," Hearing Research, vol. 205, no. 1-2, pp. 102-109, 2005.

[130] J. M. C. Gutteridge and B. Halliwell, "The measurement and mechanism of lipid peroxidation in biological systems," Trends in Biochemical Sciences, vol. 15, no. 4, pp. 129-135, 1990.

[131] B. Halliwell and J. M. C. Gutteridge, "Role of free radicals and catalytic metal ions in human disease: an overview," Methods in Enzymology, vol. 186, pp. 1-85, 1990.

[132] J. M. C. Gutteridge and B. Halliwell, "Free radicals and antioxidants in the year 2000. A historical look to the future," Annals of the New York Academy of Sciences, vol. 899, pp. 136$147,2000$.

[133] T. Yamasoba, A. L. Nuttall, C. Harris, Y. Raphael, and J. M. Miller, "Role of glutathione in protection against noiseinduced hearing loss," Brain Research, vol. 784, no. 1-2, pp. 82-90, 1998.

[134] T. Yamasoba, C. Harris, F. Shoji, R. J. Lee, A. L. Nuttall, and J. M. Miller, "Influence of intense sound exposure on glutathione synthesis in the cochlea," Brain Research, vol. 804, no. 1, pp. 72-78, 1998.

[135] S. W. Jeong, L. S. Kim, D. Hur, W. Y. Bae, J. R. Kim, and J. H. Lee, "Gentamicin-induced spiral ganglion cell death: apoptosis mediated by ROS and the JNK signaling pathway," Acta Oto-Laryngologica, vol. 130, no. 6, pp. 670-678, 2010.

[136] A. G. Cheng, L. L. Cunningham, and E. W. Rubel, "Mechanisms of hair cell death and protection," Current Opinion in Otolaryngology and Head and Neck Surgery, vol. 13, no. 6, pp. 343-348, 2005.

[137] M. X. Guan, "Mitochondrial 12S rRNA mutations associated with aminoglycoside ototoxicity," Mitochondrion, vol. 11, no. 2, pp. 237-245, 2011.

[138] P. H. Krammer, "CD95's deadly mission in the immune system," Nature, vol. 407, no. 6805, pp. 789-795, 2000.

[139] D. F. Suen, K. L. Norris, and R. J. Youle, "Mitochondrial dynamics and apoptosis," Genes and Development, vol. 22, no. 12 , pp. 1577-1590, 2008

[140] M. E. Peter and P. H. Krammer, "The CD95(APO-1/Fas) DISC and beyond," Cell Death and Differentiation, vol. 10, no. 1, pp. 26-35, 2003.

[141] D. Brenner and T. W. Mak, "Mitochondrial cell death effectors," Current Opinion in Cell Biology, vol. 21, no. 6, pp. 871-877, 2009.

[142] A. Strasser, L. O’Connor, and V. M. Dixit, "Apoptosis signaling," Annual Review of Biochemistry, vol. 69, pp. 217245,2000

[143] C. Borner, "The Bcl-2 protein family: sensors and checkpoints for life-or-death decisions," Molecular Immunology, vol. 39, no. 11, pp. 615-647, 2003.

[144] A. Gross, J. Jockel, M. C. Wei, and S. J. Korsmeyer, "Enforced dimerization of BAX results in its translocation, mitochondrial dysfunction and apoptosis," EMBO Journal, vol. 17, no. 14, pp. 3878-3885, 1998.

[145] H. Harada and S. Grant, "Apoptosis regulators," Reviews in Clinical and Experimental Hematology, vol. 7, no. 2, pp. 117138, 2003.

[146] L. Lalier, P. F. Cartron, P. Juin et al., "Bax activation and mitochondrial insertion during apoptosis," Apoptosis, vol. 12, no. 5, pp. 887-896, 2007.

[147] T. Lindsten, W. X. Zong, and C. B. Thompson, "Defining the role of the Bcl-2 family of proteins in the nervous system," Neuroscientist, vol. 11, no. 1, pp. 10-15, 2005.
[148] Z. N. Oltvai, C. L. Milliman, and S. J. Korsmeyer, "Bcl-2 heterodimerizes in vivo with a conserved homolog, Bax, that accelerates programed cell death," Cell, vol. 74, no. 4, pp. 609619, 1993.

[149] H. Xiang, Y. Kinoshita, C. M. Knudson, S. J. Korsmeyer, P. A. Schwartzkroin, and R. S. Morrison, "Bax involvement in p53-mediated neuronal cell death," Journal of Neuroscience, vol. 18, no. 4, pp. 1363-1373, 1998.

[150] D. A. Mangiardi, K. McLaughlin-Williamson, K. E. May, E. P. Messana, D. C. Mountain, and D. A. Cotanche, "Progression of hair cell ejection and molecular markers of apoptosis in the avian cochlea following gentamicin treatment," Journal of Comparative Neurology, vol. 475, no. 1, pp. 1-18, 2004.

[151] J. E. Lee, T. Nakagawa, T. S. Kim et al., "Signaling pathway for apoptosis of vestibular hair cells of Mice due to aminoglycosides," Acta Oto-Laryngologica, vol. 124, supplement 551, pp. 69-74, 2004.

[152] J. I. Matsui, J. E. Gale, and M. E. Warchol, "Critical signaling events during the aminoglycoside-induced death of sensory hair cells in vitro," Journal of Neurobiology, vol. 61, no. 2, pp. 250-266, 2004.

[153] N. Dehne, U. Rauen, H. de Groot, and J. Lautermann, "Involvement of the mitochondrial permeability transition in gentamicin ototoxicity," Hearing Research, vol. 169, no. 1-2, pp. 47-55, 2002.

[154] T. Nakagawa and H. Yamane, "Cytochrome c redistribution in apoptosis of guinea pig vestibular hair cells," Brain Research, vol. 847, no. 2, pp. 357-359, 1999.

[155] L. L. Cunningham, J. I. Matsui, M. E. Warchol, and E. W. Rubel, "Overexpression of Bcl-2 prevents neomycin-induced hair cell death and caspase- 9 activation in the adult mouse utricle in vitro," Journal of Neurobiology, vol. 60, no. 1, pp. 89-100, 2004.

[156] C. Bonny, A. Oberson, S. Negri, C. Sauser, and D. F. Schorderet, "Cell-permeable peptide inhibitors of JNK. Novel blockers of $\beta$-cell death," Diabetes, vol. 50, no. 1, pp. 77-82, 2001.

[157] M. Dickens, J. S. Rogers, J. Cavanagh et al., "A cytoplasmic inhibitor of the JNK signal transduction pathway," Science, vol. 277, no. 5326, pp. 693-696, 1997.

[158] Y. T. Ip and R. J. Davis, "Signal transduction by the cJun N-terminal kinase (JNK) - From inflammation to development," Current Opinion in Cell Biology, vol. 10, no. 2, pp. 205-219, 1998.

[159] A. Zine and T. R. Van De Water, "The MAPK/JNK signalling pathways offers potential therapeutic targets for the prevention of acquired deafness," Current Drug Targets: CNS and Neurological Disorders, vol. 3, no. 4, pp. 325-332, 2004.

[160] J. Liu and A. Lin, "Role of JNK activation in apoptosis: a double-edged sword," Cell Research, vol. 15, no. 1, pp. 36-42, 2005.

[161] J. Wang, T. R. Van De Water, C. Bonny, F. De Ribaupierre, J. L. Puel, and A. Zine, "A peptide inhibitor of c-Jun Nterminal kinase protects against both aminoglycoside and acoustic trauma-induced auditory hair cell death and hearing loss," Journal of Neuroscience, vol. 23, no. 24, pp. 8596-8607, 2003.

[162] U. Pirvola, L. Xing-Qun, J. Virkkala et al., "Rescue of hearing, auditory hair cells, and neurons by CEP-1347/KT7 an inhibitor of c-Jun N-terminal kinase activation," Journal of Neuroscience, vol. 20, no. 1, pp. 43-50, 2000.

[163] X. Liu, C. N. Kim, J. Yang, R. Jemmerson, and X. Wang, "Induction of apoptotic program in cell-free extracts: 
requirement for dATP and cytochrome c," Cell, vol. 86, no. 1, pp. 147-157, 1996.

[164] H. R. Stennicke and G. S. Salvesen, "Caspases—controlling intracellular signals by protease zymogen activation," Biochimica et Biophysica Acta, vol. 1477, no. 1-2, pp. 299-306, 2000.

[165] M. Muzio, B. R. Stockwell, H. R. Stennicke, G. S. Salvesen, and V. M. Dixit, "An induced proximity model for caspase-8 activation," Journal of Biological Chemistry, vol. 273, no. 5, pp. 2926-2930, 1998.

[166] L. L. Cunningham, A. G. Cheng, and E. W. Rubel, "Caspase activation in hair cells of the mouse utricle exposed to neomycin," Journal of Neuroscience, vol. 22, no. 19, pp. 8532 8540, 2002.

[167] A. G. Cheng, L. L. Cunningham, and E. W. Rubel, "Hair cell death in the avian basilar papilla: characterization of the in vitro model and caspase activation," Journal of the Association for Research in Otolaryngology, vol. 4, no. 1, pp. 91-105, 2003.

[168] J. Wang, S. Ladrech, R. Pujol, P. Brabet, T. R. Van De Water, and J. L. Puel, "Caspase inhibitors, but not c-Jun NH2-terminal kinase inhibitor treatment, prevent cisplatininduced hearing loss," Cancer Research, vol. 64, no. 24, pp. 9217-9224, 2004.

[169] D. Bodmer, D. Brors, K. Pak, M. Bodmer, and A. F. Ryan, "Gentamicin-induced hair cell death is not dependent on the apoptosis receptor Fas," Laryngoscope, vol. 113, no. 3, pp. 452-455, 2003.

[170] J. Yuan and B. A. Yankner, "Caspase activity sows the seeds of neuronal death," Nature Cell Biology, vol. 1, no. 2, pp. E4445, 1999.

[171] E. H. Y. Cheng, D. G. Kirsch, R. J. Clem et al., "Conversion of Bcl-2 to a bax-like death effector by caspases," Science, vol. 278, no. 5345, pp. 1966-1968, 1997.

[172] Y. A. Lazebnik, S. H. Kaufmann, S. Desnoyers, G. G. Poirier, and W. C. Earnshaw, "Cleavage of poly(ADP-ribose) polymerase by a proteinase with properties like ICE," Nature, vol. 371, no. 6495, pp. 346-347, 1994.

[173] D. G. Kirsch, A. Doseff, B. N. Chau et al., "Caspase-3dependent cleavage of Bcl-2 promotes release of cytochrome c," Journal of Biological Chemistry, vol. 274, no. 30, pp. 2115521161, 1999.

[174] S. Kothakota, T. Azuma, C. Reinhard et al., "Caspase-3generated fragment of gelsolin: effector of morphological change in apoptosis," Science, vol. 278, no. 5336, pp. 294-298, 1997.

[175] J. B. Kim, J. Y. Jung, J. C. Ahn, C. K. Rhee, and H. J. Hwang, "Antioxidant and anti-apoptotic effect of melatonin on the vestibular hair cells of rat utricles," Clinical and Experimental Otorhinolaryngology, vol. 2, no. 1, pp. 6-12, 2009.

[176] A. Caelers, V. Radojevic, J. Traenkle, Y. Brand, and D. Bodmer, "Stress and survival pathways in the mammalian cochlea," Audiology and Neurotology, vol. 15, no. 5, pp. 282290, 2010.

[177] J. Momiyama, T. Hashimoto, A. Matsubara, K. Futai, A. Namba, and H. Shinkawa, "Leupeptin, a calpain inhibitor, protects inner ear hair cells from aminoglycoside ototoxicity," Tohoku Journal of Experimental Medicine, vol. 209, no. 2, pp. 89-97, 2006.

[178] A. Forge and L. Li, "Apoptotic death of hair cells in mammalian vestibular sensory epithelia," Hearing Research, vol. 139, no. 1-2, pp. 97-115, 2000.

[179] J. A. Williams and N. Holder, "Cell turnover in neuromasts of zebrafish larvae," Hearing Research, vol. 143, no. 1-2, pp. 171-181, 2000.
[180] J. I. Matsui, A. Haque, D. Huss et al., "Caspase inhibitors promote vestibular hair cell survival and function after aminoglycoside treatment in vivo," Journal of Neuroscience, vol. 23, no. 14, pp. 6111-6122, 2003.

[181] T. Nakagawa, T. S. Kim, N. Murai et al., "A novel technique for inducing local inner ear damage," Hearing Research, vol. 176, no. 1-2, pp. 122-127, 2003.

[182] T. Okuda, K. Sugahara, T. Takemoto, H. Shimogori, and H. Yamashita, "Inhibition of caspases alleviates gentamicininduced cochlear damage in guinea pigs," Auris Nasus Larynx, vol. 32, no. 1, pp. 33-37, 2005.

[183] K. Sugahara, E. W. Rubel, and L. L. Cunningham, "JNK signaling in neomycin-induced vestibular hair cell death," Hearing Research, vol. 221, no. 1-2, pp. 128-135, 2006.

[184] D. Bodmer, D. Brors, M. Bodmer, and A. F. Ryan, "Rescue of auditory hair cells from ototoxicity by CEP-11 004, an inhibitor of the JNK signaling pathway," Laryngo- RhinoOtologie, vol. 81, no. 12, pp. 853-856, 2002.

[185] M. Nakamagoe, K. Tabuchi, I. Uemaetomari, B. Nishimura, and A. Hara, "Estradiol protects the cochlea against gentamicin ototoxicity through inhibition of the JNK pathway," Hearing Research, vol. 261, no. 1-2, pp. 67-74, 2010.

[186] J. Ylikoski, L. Xing-Qun, J. Virkkala, and U. Pirvola, "Blockade of c-Jun N-terminal kinase pathway attenuates gentamicin-induced cochlear and vestibular hair cell death," Hearing Research, vol. 166, no. 1-2, pp. 33-43, 2002.

[187] S. C. Pfannenstiel, M. Praetorius, P. K. Plinkert, D. E. Brough, and H. Staecker, "Bcl-2 gene therapy prevents aminoglycoside-induced degeneration of auditory and vestibular hair cells," Audiology and Neurotology, vol. 14, no. 4, pp. 254-266, 2009.

[188] Y. H. Liu, X. M. Ke, Y. Qin, Z. P. Gu, and S. F. Xiao, "Adenoassociated virus-mediated $\mathrm{Bcl}-\mathrm{xL}$ prevents aminoglycosideinduced hearing loss in mice," Chinese Medical Journal, vol. 120, no. 14, pp. 1236-1240, 2007.

[189] R. I. Morimoto, "Proteotoxic stress and inducible chaperone networks in neurodegenerative disease and aging," Genes and Development, vol. 22, no. 11, pp. 1427-1438, 2008.

[190] L. L. Cunningham and C. S. Brandon, "Heat shock inhibits both aminoglycoside- and cisplatin-induced sensory hair cell death," Journal of the Association for Research in Otolaryngology, vol. 7, no. 3, pp. 299-307, 2006.

[191] M. Taleb, C. S. Brandon, F. -S. Lee, M. I. Lomax, W. H. Dillmann, and L. L. Cunningham, "Hsp70 inhibits aminoglycoside-induced hair cell death and is necessary for the protective effect of heat shock," Journal of the Association for Research in Otolaryngology, vol. 9, no. 3, pp. 277-289, 2008.

[192] M. Taleb, C. S. Brandon, F. S. Lee, K. C. Harris, W. H. Dillmann, and L. L. Cunningham, "Hsp70 inhibits aminoglycoside-induced hearing loss and cochlear hair cell death," Cell Stress and Chaperones, vol. 14, no. 4, pp. 427-437, 2009.

[193] K. Tabuchi, K. Pak, E. Chavez, and A. F. Ryan, "Role of inhibitor of apoptosis protein in gentamicin-induced cochlear hair cell damage," Neuroscience, vol. 149, no. 1, pp. 213-222, 2007.

[194] D. Dulon, H. Hiel, C. Aurousseau, J. P. Erre, and J. M. Aran, "Pharmacokinetics of gentamicin in the sensory hair cells of the organ of Corti: rapid uptake and long term persistence," Comptes Rendus de l'Academie des Sciences Series III, vol. 316, no. 7, pp. 682-687, 1993.

[195] M. Olsson and B. Zhivotovsky, "Caspases and cancer," Cell Death and Differentiation, vol. 18, no. 9, pp. 1441-1449, 2011. 
[196] P. Sinswat, W. J. Wu, S. H. Sha, and J. Schacht, "Protection from ototoxicity of intraperitoneal gentamicin in guinea pig," Kidney International, vol. 58, no. 6, pp. 2525-2532, 2000.

[197] B. B. Song and J. Schacht, "Variable efficacy of radical scavengers and iron chelators to attenuate gentamicin ototoxicity in guinea pig in vivo," Hearing Research, vol. 94, no. 1-2, pp. 87-93, 1996.

[198] W. J. Wu, S. H. Sha, J. D. McLaren, K. Kawamoto, Y. Raphael, and J. Schacht, "Aminoglycoside ototoxicity in adult CBA, C57BL and BALB mice and the Sprague-Dawley rat," Hearing Research, vol. 158, no. 1-2, pp. 165-178, 2001.

[199] E. Lecain, B. Omri, F. Behar-Cohen, P. T. B. Huy, and P. Crisanti, "The role of PKC $\zeta$ in amikacin-induced apoptosis in the cochlea: prevention by aspirin," Apoptosis, vol. 12, no. 2, pp. 333-342, 2007.

[200] S. H. Sha and J. Schacht, "Salicylate attenuates gentamicininduced ototoxicity," Laboratory Investigation, vol. 79, no. 7, pp. 807-813, 1999.

[201] F. Behnoud, K. Davoudpur, and M. T. Goodarzi, "Can aspirin protect or at least attenuate gentamicin ototoxicity in humans?" Saudi Medical Journal, vol. 30, no. 9, pp. 1165$1169,2009$.

[202] Y. Chen, W. G. Huang, D. J. Zha et al., "Aspirin attenuates gentamicin ototoxicity: from the laboratory to the clinic," Hearing Research, vol. 226, no. 1-2, pp. 178-182, 2007.

[203] S. H. Sha, J. H. Qiu, and J. Schacht, "Aspirin to prevent gentamicin-induced hearing loss," The New England Journal of Medicine, vol. 354, no. 17, pp. 1856-1857, 2006.

[204] E. N. Myers and J. M. Bernstein, "Salicylate ototoxicity; a clinical and experimental study," Archives of Otolaryngology, vol. 82, no. 5, pp. 483-493, 1965.

[205] G. D. Chen, M. H. Kermany, A. D’Elia et al., "Too much of a good thing: long-term treatment with salicylate strengthens outer hair cell function but impairs auditory neural activity," Hearing Research, vol. 265, no. 1-2, pp. 63-69, 2010.

[206] M. D. Hilty, C. A. Romshe, and P. V. Delamater, "Reye's syndrome and hyperaminoacidemia," Journal of Pediatrics, vol. 84, no. 3, pp. 362-365, 1974.

[207] R. D. K. Reye, G. Morgan, and J. Baral, "Encephalopathy and fatty degeneration of the viscera. A disease entity in childhood," The Lancet, vol. 282, no. 7311, pp. 749-752, 1963.

[208] I. Tanret and D. Duh, “The Reye syndrome," Journal de Pharmacie de Belgique, vol. 1, pp. 13-15, 2011.

[209] S. H. Sha, G. Zajic, C. J. Epstein, and J. Schacht, "Overexpression of copper/zinc-superoxide dismutase protects from kanamycin-induced hearing loss," Audiology and NeuroOtology, vol. 6, no. 3, pp. 117-123, 2001.

[210] L. Feldman, S. Efrati, E. Eviatar et al., "Gentamicin-induced ototoxicity in hemodialysis patients is ameliorated by $\mathrm{N}$ acetylcysteine," Kidney International, vol. 72, no. 3, pp. 359363, 2007.

[211] K. C. M. Campbell, R. P. Meech, J. J. Klemens et al., "Prevention of noise- and drug-induced hearing loss with dmethionine," Hearing Research, vol. 226, no. 1-2, pp. 92-103, 2007.

[212] S. H. Sha and J. Schacht, "Antioxidants attenuate gentamicininduced free radical formation in vitro and ototoxicity in vivo: D-methionine is a potential protectant," Hearing Research, vol. 142, no. 1-2, pp. 34-40, 2000.

[213] M. Takumida, M. Anniko, A. Shimizu, and H. Watanabe, "Neuroprotection of vestibular sensory cells from gentamicin ototoxicity obtained using nitric oxide synthase inhibitors, reactive oxygen species scavengers, brain-derived neurotrophic factors and calpain inhibitors," Acta OtoLaryngologica, vol. 123, no. 1, pp. 8-13, 2003.

[214] B. J. Conlon, J. M. Aran, J. P. Erre, and D. W. Smith, "Attenuation of aminoglycoside-induced cochlear damage with the metabolic antioxidant $\alpha$-lipoic acid," Hearing Research, vol. 128, no. 1-2, pp. 40-44, 1999.

[215] A. R. Fetoni, B. Sergi, A. Ferraresi, G. Paludetti, and D. Troiani, " $\alpha$-Tocopherol protective effects on gentamicin ototoxicity: an experimental study," International Journal of Audiology, vol. 43, no. 3, pp. 166-171, 2004.

[216] A. R. Fetoni, B. Sergi, E. Scarano, G. Paludetti, A. Ferraresi, and D. Troiani, "Protective effects of $\alpha$-tocopherol against gentamicin-induced oto-vestibulo toxicity: an experimental study," Acta Oto-Laryngologica, vol. 123, no. 2, pp. 192-197, 2003.

[217] B. Sergi, A. R. Fetoni, A. Ferraresi et al., "The role of antioxidants in protection from ototoxic drugs," Acta OtoLaryngologica, vol. 124, no. 552, supplement, pp. 42-45, 2004.

[218] S. L. Garetz, D. J. Rhee, and J. Schacht, "Sulfhydryl compounds and antioxidants inhibit cytotoxicity to outer hair cells of a gentamicin metabolite in vitro," Hearing Research, vol. 77, no. 1-2, pp. 75-80, 1994.

[219] H. W. Jung, S. O. Chang, C. S. Kim, C. S. Rhee, and D. H. Lim, "Effects of Ginkgo biloba extract on the cochlear damage induced by local gentamicin installation in guinea pigs," Journal of Korean Medical Science, vol. 13, no. 5, pp. 525-528, 1998.

[220] A. M. Wang et al., "Tanshinone (Salviae miltiorrhizae extract) preparations attenuate aminoglycoside-induced free radical formation in vitro and ototoxicity in vivo," Antimicrobial Agents and Chemotherapy, vol. 47, no. 6, pp. 1836-1841, 2003.

[221] T. Erdem, O. Ozturan, M. Iraz, M. C. Miman, and E. Olmez, "Dose-dependent dual effect of melatonin on ototoxicity induced by amikacin in adult rats," European Archives of OtoRhino-Laryngology, vol. 262, no. 4, pp. 314-321, 2005.

[222] L. F. Ye, Z. Z. Tao, Q. Q. Hua et al., "Protective effect of melatonin against gentamicin ototoxicity," Journal of Laryngology and Otology, vol. 123, no. 6, pp. 598-602, 2009.

[223] M. A. Lopez-Gonzalez, J. M. Guerrero, R. Torronteras, C. Osuna, and F. Delgado, "Ototoxicity caused by aminoglycosides is ameliorated by melatonin without interfering with the antibiotic capacity of the drugs," Journal of Pineal Research, vol. 28, no. 1, pp. 26-33, 2000.

[224] K. Kawamoto, S. H. Sha, R. Minoda et al., "Antioxidant gene therapy can protect hearing and hair cells from ototoxicity," Molecular Therapy, vol. 9, no. 2, pp. 173-181, 2004.

[225] S. L. McFadden, D. Ding, D. Salvemini, and R. J. Salvi, "M40403, a superoxide dismutase mimetic, protects cochlear hair cells from gentamicin, but not cisplatin toxicity," Toxicology and Applied Pharmacology, vol. 186, no. 1, pp. 4654, 2003.

[226] M. S. Asplund, A. Lidian, B. Linder, M. Takumida, and M. Anniko, "Protective effect of edaravone against tobramycininduced ototoxicity," Acta Oto-Laryngologica, vol. 129, no. 1, pp. 8-13, 2009.

[227] S. Bonabi, A. Caelers, A. Monge, A. Huber, and D. Bodmer, "Resveratrol protects auditory hair cells from gentamicin toxicity," Ear, Nose and Throat Journal, vol. 87, no. 10, pp. 570-573, 2008.

[228] S. L. Garetz, R. A. Altschuler, and J. Schacht, "Attenuation of gentamicin ototoxicity by glutathione in the guinea pig in vivo," Hearing Research, vol. 77, no. 1-2, pp. 81-87, 1994. 
[229] B. J. Conlon and D. W. Smith, "Topical aminoglycoside ototoxicity: attempting to protect the cochlea," Acta OtoLaryngologica, vol. 120, no. 5, pp. 596-599, 2000.

[230] E. N. Maudonnet, J. A. A. De Oliveira, M. Rossato, and M. A. Hyppolito, "Gentamicin attenuates gentamicin-induced ototoxicity - Self-protection," Drug and Chemical Toxicology, vol. 31, no. 1, pp. 11-25, 2008.

[231] J. A. A. De Oliveira, D. M. Canedo, M. Rossato, and M. H. De Andrade, "Self-protection against aminoglycoside ototoxicity in guinea pigs," Otolaryngology-Head and Neck Surgery, vol. 131, no. 3, pp. 271-279, 2004.

[232] A. C. Suryadevara, H. H. Wanamaker, and A. Pack, "The effects of sound conditioning on gentamicin-induced vestibulocochlear toxicity in gerbils," Laryngoscope, vol. 119, no. 6, pp. 1166-1170, 2009.

[233] A. S. Basile, J. M. Huang, C. Xie, D. Webster, C. Berlin, and P. Skolnick, "N-Methyl-D-aspartate antagonists limit aminoglycoside antibiotic-induced hearing loss," Nature Medicine, vol. 2, no. 12, pp. 1338-1343, 1996.

[234] A. S. Basile, A. M. Brichta, B. D. Harris, D. Morse, D. Coling, and P. Skolnick, "Dizocilpine attenuates streptomycininduced vestibulotoxicity in rats," Neuroscience Letters, vol. 265, no. 2, pp. 71-74, 1999.

[235] W. J. O'Sullivan, "Stability constants of metal complexes," in Data for Biochemical Research, D. C. E. R. M. C. Dawson and A . K. M. J. W. H. Elliott, Eds., Oxford Clarendon Press, Oxford, UK, 1969.

[236] C. F. Babbs and M. G. Steiner, "Detection and quantitation of hydroxyl radical using dimethyl sulfoxide as molecular probe," Methods in Enzymology, vol. 186, pp. 137-147, 1990.

[237] S. H. Sha and J. Schacht, "Are aminoglycoside antibiotics excitotoxic?” NeuroReport, vol. 9, no. 17, pp. 3893-3895, 1998.

[238] R. Pujol, "Lateral and medial efferents: a double neurochemical mechanism to protect and regulate inner and outer hair cell function in the cochlea," British Journal of Audiology, vol. 28, no. 4-5, pp. 185-191, 1994.

[239] E. Hokkanen, "The aggravating effect of some antibiotics on the neuromuscular blockade in myasthenia gravis," Acta Neurologica Scandinavica, vol. 40, pp. 346-352, 1964.

[240] R. W. Barrons, "Drug-induced neuromuscular blockade and myasthenia gravis," Pharmacotherapy, vol. 17, no. 6, pp. 1220-1232, 1997.

[241] C. Lee et al., "Neuromuscular block by neomycin in the cat," Canadian Anaesthetists' Society Journal, vol. 23, no. 5, pp. 527-533, 1976.

[242] J. S. Kass and W. X. Shandera, "Nervous system effects of antituberculosis therapy," CNS Drugs, vol. 24 , no. 8, pp. 655 $667,2010$.

[243] J. F. Fiekers, "Effects of the aminoglycoside antibiotics, streptomycin and neomycin, on neuromuscular transmission. I. Presynaptic considerations," Journal of Pharmacology and Experimental Therapeutics, vol. 225, no. 3, pp. 487-495, 1983.

[244] J. F. Fiekers, "Effects of the aminoglycoside antibiotics, streptomycin and neomycin, on neuromuscular transmission. II. Postsynaptic considerations," Journal of Pharmacology and Experimental Therapeutics, vol. 225, no. 3, pp. 496-502, 1983.

[245] A. Alharazneh, L. Luk, M. Huth et al., "Functional hair cell mechanotransducer channels are required for aminoglycoside ototoxicity," PLoS ONE, vol. 6, no. 7, article e22347, 2011.

[246] I. Lopez, V. Honrubia, S. C. Lee et al., "The protective effect of brain-derived neurotrophic factor after gentamicin ototoxicity," American Journal of Otology, vol. 20, no. 3, pp. 317-324, 1999.

[247] M. Takumida and M. Anniko, "Brain-derived neurotrophic factor and nitric oxide synthase inhibitor protect the vestibular organ against gentamicin ototoxicity," Acta OtoLaryngologica, vol. 122, no. 1, pp. 10-15, 2002.

[248] R. S. Ruan, S. K. Leong, I. Mark, and K. H. Yeoh, "Effects of BDNF and NT-3 on hair cell survival in guinea pig cochlea damaged by kanamycin treatment," NeuroReport, vol. 10, no. 10, pp. 2067-2071, 1999.

[249] C. He, S. J. Kang, Y. Dou et al., "Ciliary neurotrophic factor antagonizes gentamicin-induced alterations of electric potentials in auditory pathway in guinea pigs," Acta Pharmacologica Sinica, vol. 17, no. 6, pp. 493-496, 1996.

[250] R. Kuang, G. Hever, G. Zajic et al., "Glial cell line-derived neurotrophic factor. Potential for otoprotection," Annals of the New York Academy of Sciences, vol. 884, pp. 270-291, 1999.

[251] L. N. Gillespie, G. M. Clark, P. F. Bartlett, and P. L. Marzella, "BDNF-induced survival of auditory neurons in vivo: cessation of treatment leads to accelerated loss of survival effects," Journal of Neuroscience Research, vol. 71, no. 6, pp. 785-790, 2003.

[252] D. Ding, H. Jiang, and R. J. Salvi, "Mechanisms of rapid sensory hair-cell death following co-administration of gentamicin and ethacrynic acid," Hearing Research, vol. 259, no. 1-2, pp. 16-23, 2010.

[253] D. Ding, S. L. McFadden, R. W. Browne, and R. J. Salvi, "Late dosing with ethacrynic acid can reduce gentamicin concentration in perilymph and protect cochlear hair cells," Hearing Research, vol. 185, no. 1-2, pp. 90-96, 2003.

[254] R. H. Mathog and W. J. Klein, "Ototoxicity of ethacrynic acid and aminoglycoside antibiotics in uremia," The New England Journal of Medicine, vol. 280, no. 22, pp. 1223-1224, 1969.

[255] M. Takumida and M. Anniko, "Isosorbide delays gentamicininduced vestibular sensory cell death," ORL, vol. 67, no. 5, pp. 276-281, 2005.

[256] M. Duan, K. Agerman, P. Ernfors, and B. Canlon, "Complementary roles of neurotrophin 3 and a $\mathrm{N}$-methyl-D-aspartate antagonist in the protection of noise and aminoglycosideinduced ototoxicity," Proceedings of the National Academy of Sciences of the United States of America, vol. 97, no. 13, pp. 7597-7602, 2000.

[257] K. Kawamoto, M. Yagi, T. Stöver, S. Kanzaki, and Y. Raphael, "Hearing and hair cells are protected by adenoviral gene therapy with TGF- $\beta 1$ and GDNF," Molecular Therapy, vol. 7, no. 4, pp. 484-492, 2003.

[258] M. Suzuki, M. Yagi, J. N. Brown, A. L. Miller, J. M. Miller, and Y. Raphael, "Effect of transgenic GDNF expression on gentamicin-induced cochlear and vestibular toxicity," Gene Therapy, vol. 7, no. 12, pp. 1046-1054, 2000.

[259] M. Yagi, E. Magal, Z. Sheng, K. A. Ang, and Y. Raphael, "Hair cell protection from aminoglycoside ototoxicity by adenovirus-mediated overexpression of glial cell line-derived neurotrophic factor," Human Gene Therapy, vol. 10, no. 5, pp. 813-823, 1999.

[260] R. Fettiplace, A. J. Ricci, and C. M. Hackney, "Clues to the cochlear amplifier from the turtle ear," Trends in Neurosciences, vol. 24, no. 3, pp. 169-175, 2001.

[261] A. J. Hudspeth, Y. Choe, A. D. Mehta, and P. Martin, "Putting ion channels to work: mechanoelectrical transduction, adaptation, and amplification by hair cells," Proceedings of the National Academy of Sciences of the United States of America, vol. 97, no. 22, pp. 11765-11772, 2000. 
[262] K. McQuillen, "The bacterial surface IV. Effect of streptomycin on the electrophoretic mobility of escherichia coli and Staphylococcus aureus," Biochimica et Biophysica Acta, vol. 7, no. 1, pp. 54-60, 1951.

[263] R. E.W. Hancock and A. Bell, "Antibiotic uptake into gramnegative bacteria," European Journal of Clinical Microbiology and Infectious Diseases, vol. 7, no. 6, pp. 713-720, 1988.

[264] G. G. Jackson, V. T. Lolans, and G. L. Daikos, "The inductive role of ionic binding in the bactericidal and postexposure effects of aminoglycoside antibiotics with implications for dosing," Journal of Infectious Diseases, vol. 162, no. 2, pp. 408413, 1990. 


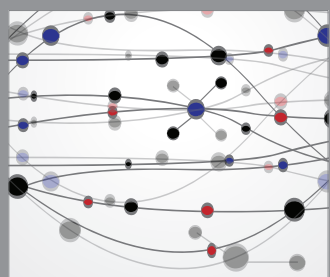

The Scientific World Journal
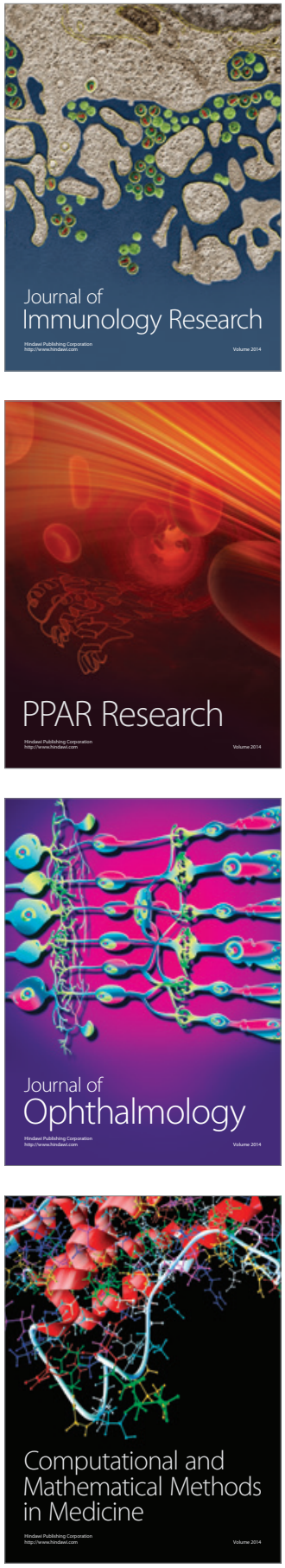

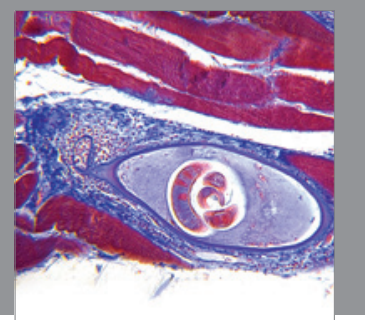

Gastroenterology

Research and Practice
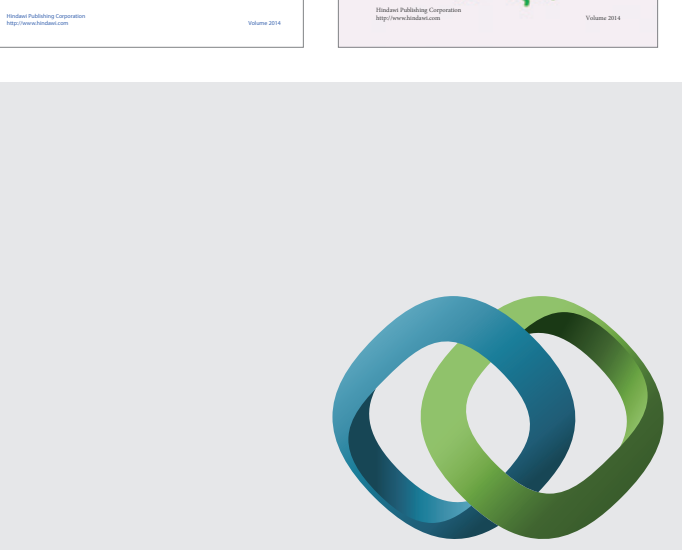

\section{Hindawi}

Submit your manuscripts at

http://www.hindawi.com
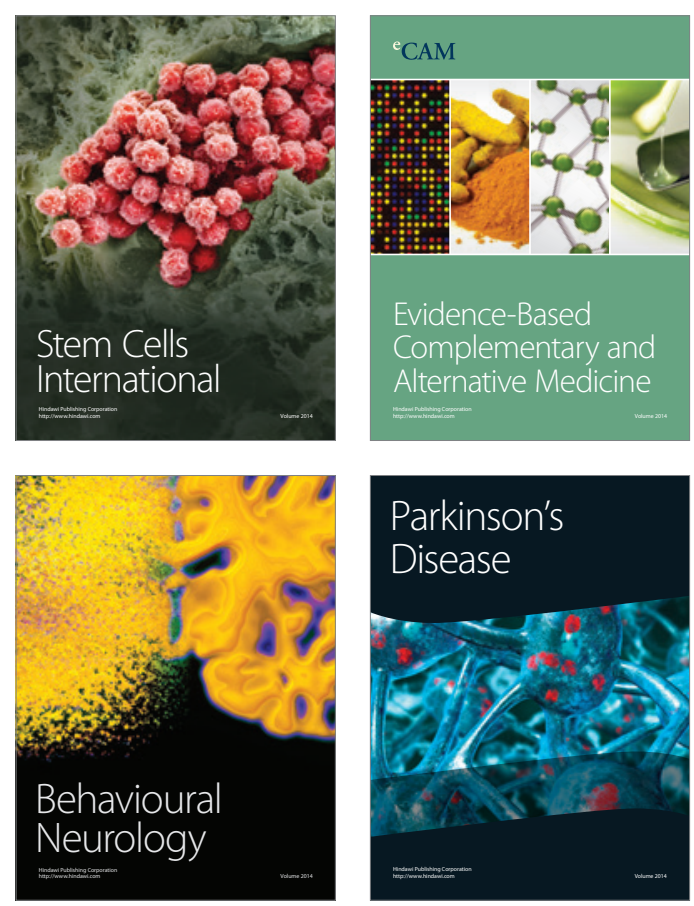

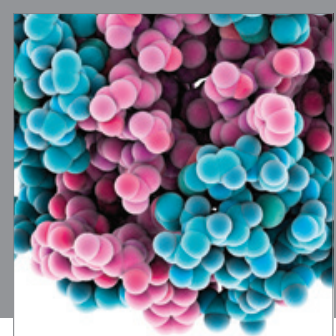

Journal of
Diabetes Research

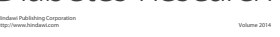

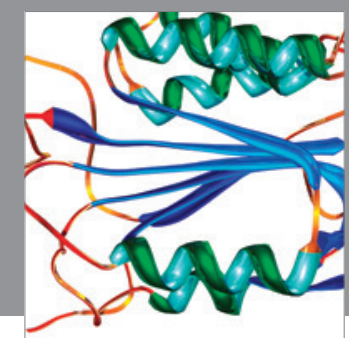

Disease Markers
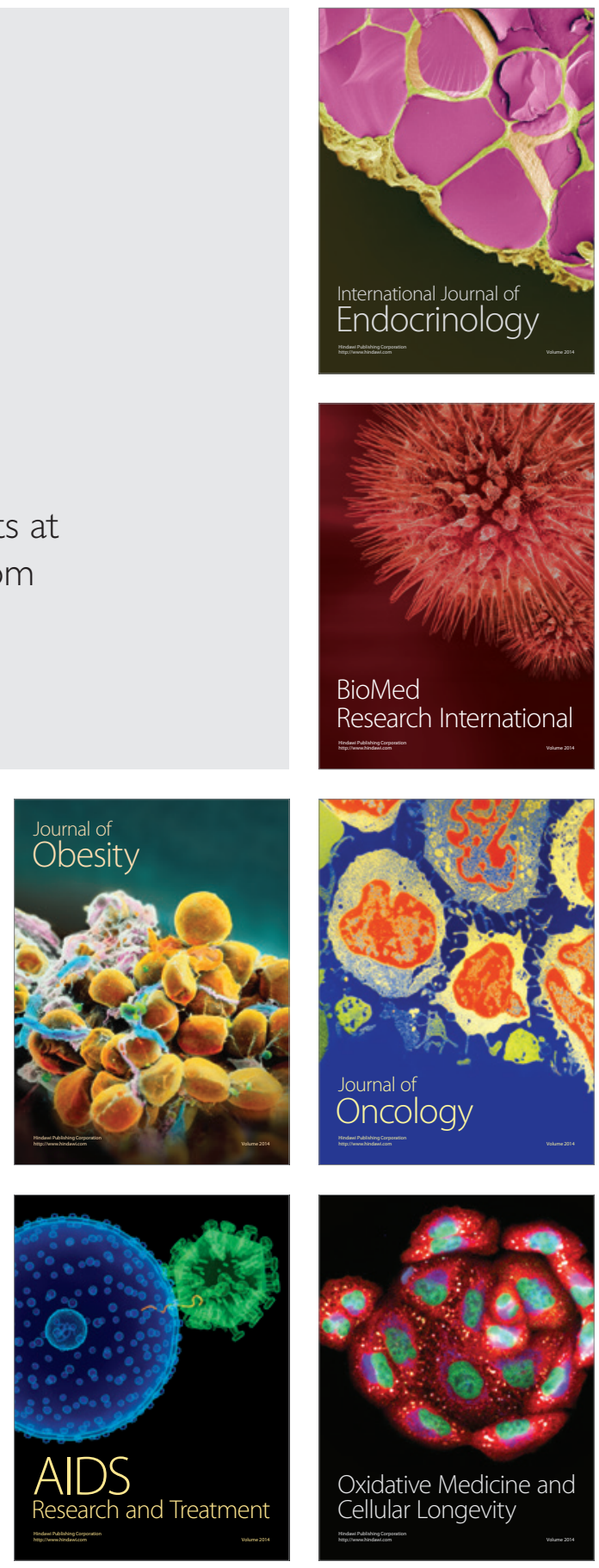